Erika Cisi Domingues

\title{
Hipersensibilidade a inalantes e alimentos nos distúrbios do equilíbrio corporal
}

Tese apresentada à Faculdade de Medicina da Universidade de São Paulo para obtenção do título de Doutor em Ciências

Área de concentração: Otorrinolaringologia

Orientadora: Profa. Dra. Roseli Saraiva Moreira Bittar

São Paulo

2010 
Dados Internacionais de Catalogação na Publicação (CIP)

Preparada pela Biblioteca da

Faculdade de Medicina da Universidade de São Paulo

\section{Creprodução autorizada pelo autor}

Domingues, Erika Cisi

Hipersensibilidade a inalantes e alimentos nos distúrbios do equilíbrio corporal /

Erika Cisi Domingues. -- São Paulo, 2010.

Tese(doutorado)--Faculdade de Medicina da Universidade de São Paulo.

Departamento de Oftalmologia e Otorrinolaringologia.

Área de concentração: Otorrinolaringologia.

Orientadora: Roseli Saraiva Moreira Bittar.

Descritores: 1.Tontura 2.Zumbido 3.Hipersensibilidade imediata

USP/FM/SBD-047/10 
Dedico este trabalho de tese à minha família que me deu todo o suporte para chegar até aqui. Minha família é a razão da minha vida! 


\section{AGRADECIMENTOS}

Agradeço ...

À Dr ${ }^{\mathrm{a}}$ Roseli Saraiva Moreira Bittar pela paciente orientação e por sua excepcional capacidade científica.

Ao Prof Dr João Ferreira de Mello Junior pelas suas brilhantes colocações.

Ao Dr Marco Aurélio Bottino pelo carinho e apoio nestes anos de pesquisa.

À Prof ${ }^{\mathrm{a}}$ Dr $^{\mathrm{a}}$ Tanit Ganz Sanchez pelos seus apontamentos.

A todos os pacientes que participararam deste estudo, permitindo a elaboração de cada página que se segue.

À minha mãe Ildenir Cisi Domingues por estar sempre tão presente na minha vida, me incentivando a lutar sempre.

Ao meu pai, Agostinho Domingues (em memória) que eu gostaria muito que estivesse aqui, neste momento, pelo qual ele tanto se orgulhou.

Ao meu avô, Guido Giocondo Cisi (em memória) por todo apoio que sempre me dedicou.

Ao meu filhinho, Vinícius Domingues Romeiro pela paciência e carinho.

Ao meu esposo, André Luiz Weber Romeiro pela constante ajuda que me permitiu a dedicação ao meu trabalho.

À minha irmã, Naïla Cisi Domingues e ao meu cunhado, Paulo Roberto M. de Sá, pelo incentivo e companheirismo. 
A todos os meus colegas do ambulatório de Otoneurologia, especialmente Maruska, Patrícia, Ítalo, Lucinda e Mário pelas brilhantes contribuições.

Aos queridos funcionários do ambulatório da Otorrino em especial, Milva e Cidinha, pelo carinho nas horas difíceis.

Às queridas funcionárias da secretaria da Otorrino, em especial, Márcia e Marileide, pela atenção.

Enfim, agradeço a Deus por estar sempre presente na minha vida, guiando meus passos! 
Lista de abreviaturas $\quad$ vii

Lista de símbolos e siglas viii

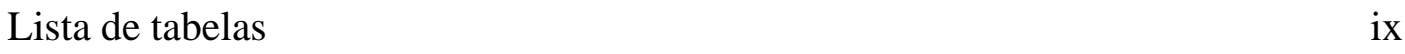

Resumo $x$

Summary - xii

Instructions to authors xiii

Artigo submetido $\quad$ xxii

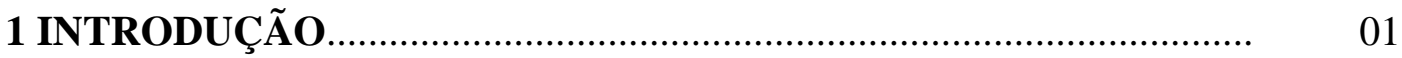

2 OBJETIVO

3 REVISÃO DE LITERATURA ................................................... 08

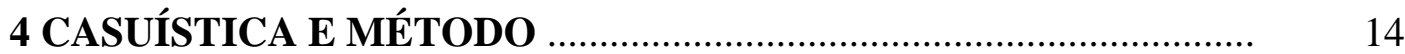

4.1 Casuística ….................................................................................. 15

4.1.1 Critérios de inclusão ..................................................................... 16

4.1.2 Critérios de exclusão ................................................................... 16

4.2 Método ....................................................................................... 16

4.2.1 Caracterização clínica ....................................................................... 16

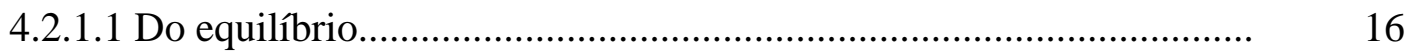

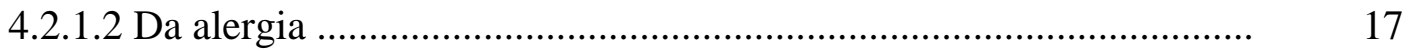

4.2.2 Teste alérgico ............................................................................ 17

4.2.2.1 Aplicação do teste ....................................................................... 18

4.2.3 Variáveis analisadas ..................................................................... 18

4.3 Análise estatística ............................................................................... 19

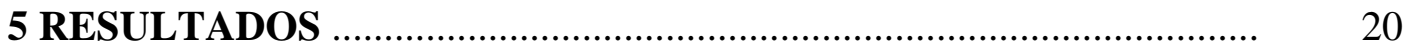

5.1 Prick test .......................................................................................... 21 
6 DISCUSSÃO

7 CONCLUSÃO

8 ANEXOS

ANEXO A - Questionário para caracterização clínica de tontura, audição e/ou zumbido

ANEXO B - Questionário de sintomatologia alérgica a inalantes e alimentos

ANEXO C - Relação dos sintomas referidos aos alérgenos e da resposta específica ao prick test entre os pacientes da amostra que apresentaram prick test positivo

ANEXO D - Relação dos alérgenos em cada paciente com resposta positiva ao prick test

9 REFERÊNCIAS

\section{APÊNDICE}




\section{LISTA DE ABREVIATURAS}

$\begin{array}{ll}\text { CD4 } & \text { grupamento de diferenciação } 4 \text { ou cluster of differentation } \\ \text { DM } & \text { Doença de Ménière } \\ \text { EcoG } & \text { eletrococleografia } \\ \text { HCFMUSP } & \text { Hospital das Clínicas da Faculdade de Medicina da } \\ & \text { Universidade de São Paulo } \\ \text { Ig } & \text { imunoglobulina } \\ \text { IgE } & \text { imunoglobulina E } \\ \text { IgG } & \text { imunoglobulina G } \\ \text { ICC } & \text { imunocomplexos circulantes } \\ \text { RSS } & \text { reações sorológicas para sífilis }\end{array}$




\section{LISTA DE SÍMBOLOS E SIGLAS}

$\begin{array}{ll}\mathrm{cm} & \text { centímetro } \\ { }^{0} \mathrm{C} & \text { grau centígrado } \\ \mathrm{IC}_{95 \%} & \text { intervalo de confiança de 95\% } \\ \mathrm{N} & \text { quantidade de pacientes } \\ \mathrm{p} & \text { significância } \\ \% & \text { porcento } \\ = & \text { igual } \\ 0 & \text { grau }\end{array}$




\section{LISTA DE TABELAS}

Tabela 1 Alérgenos testados nos pacientes participantes do presente estudo

Tabela 2 Quantificação dos tipos clínicos de tontura apresentada por 75 pacientes da amostra.

Tabela 3 Distribuição dos diversos tipos de tontura em pacientes com prick test positivo e com prick test negativo

Tabela 4 Distribuição dos pacientes com zumbido segundo sua frequência, nos grupos de pacientes com prick test positivo ou negativo 


\section{RESUMO}

Domingues EC. Hipersensibilidade a inalantes e alimentos nos distúrbios do equilíbrio corporal [tese]. São Paulo: Faculdade de Medicina, Universidade de São Paulo; 2009. 85 pág.

Introdução: O saco endolinfático tem sido apontado como o alvo das reações imuno-alérgicas da orelha interna. A prevalência de alergia em pacientes com Doença de Ménière foi estabelecida em torno de 41,6\% para inalantes e 26,6\% para alimentos, por Derebery em 2000, dados aumentados em relação à prevalência de alergia na população em geral, que, no Brasil, varia de $9 \%$ a 30\% para inalantes e de 1\% a 3\% para alimentos. Objetivos: Avaliar a prevalência de reações de hipersensibilidade tipo I a inalantes e alimentos na população do setor de Otoneurologia do Hospital das Clínicas da Faculdade de Medicina de São Paulo e descrever os sintomas vestibulares dos pacientes. Casuística e método: Setenta e cinco pacientes com distúrbios do equilíbrio de origem periférica foram submetidos a questionário de caracterização clínica de sintomas cócleo-vestibulares e teste cutâneo (prick test) para 13 inalantes e 5 alimentos. Resultados: Vinte e cinco (33,3\%) pacientes apresentaram prick test positivo a pelo menos um alérgeno inalante e 6 (8\%) a pelo menos um alérgeno alimentar. Quatro pacientes apresentaram prick test positivo na ausência de sintomas alérgicos. Prevaleceu a queixa de tontura de caráter rotatório em proporções semelhantes entre os pacientes com prick test positivo e negativo. Conclusão: A prevalência de reações de hipersensibilidade tipo I a inalantes e a alimentos na população avaliada foi maior do que na população em geral. Os sintomas vestibulares não diferiram entre os pacientes da amostra, com prick test positivo ou negativo. No entanto, deve-se obter maior número de amostra para que os dados sejam confiáveis.

DESCRITORES: tontura, zumbido, reações de hipersensibilidade tipo I 


\section{SUMMARY}

Domingues EC. Hypersensitivity to inhalants and foods in corporal equilibrium disturbs. [thesis]. "São Paulo: Faculdade de Medicina, Universidade de São Paulo”; 2009. 85pp.

Introduction: The endolymphatic sac has been pointed out as the target of immunoallergic reactions in the inner ear. The prevalence of allergy in patients with Ménière's disease was established as approximately 41,6\% for inhalants and 26,6\% for food by Derebery in 2000, an increase in the data in relation to that of the prevalence of allergy in the general population, which in Brazil varies from $9 \%$ to $30 \%$ for inhalants and from $1 \%$ to $3 \%$ for food. Objectives: To evaluate the prevalence of reactions to type I hypersensitivity to inhalants and food in the population of the Otoneurological Section of the Clinics Hospital of the University of São Paulo Medicine School and to describe the vestibular symptoms of the patients. Method: Seventy-five patients with peripheral equilibrium disturbances who had answered a questionnaire of clinical characterization regarding cochlear-vestibular symptoms and undergone prick test for 13 inhalants and 5 types of food. Results: Twenty-five $(33,3 \%)$ of the patients were positive for the prick test and for at least one allergen inhalant and 6 (8\%) for at least one food allergen. Four patients were positive for the prick test in the absence of allergy symptoms. There was a prevalence of the complaint of rotatory dizziness in similar proportions among the patients with positive and negative prick test. Conclusion: The presence of type I hypersensitivity reactions to inhalants and food in the population evaluated was greater than in the general population. The vestibular symptoms did not differ among the patients in the sample, neither with positive or negative prick test results. However, a sample of greater number should be obtained for a higher confidence level of data results.

KEYWORDS: dizziness, tinnitus, type I hypersensitivity reactions. 


\section{Revue de Laringologie Otologie Rhinologie}

\section{Recommandations aux auteurs}

\section{PREPARATI ON DE L'ARTICLE:}

Les auteurs sont priés de bien vouloir remettre à la Rédaction leurs manuscrits (l'original +1 photocopie) correctement rédigés en langue française ou anglaise, dactylographiés en double interligne. La première page mentionnera seulement le titre de l'article, les noms et prénoms des auteurs, l'adresse complète du service. Les légendes seront regroupées à la fin sur une feuille séparée. Pour les articles enregistrés sur ordinateur, merci d'adresser en plus des deux exemplaires demandés (au-dessus), la disquette informatique (en format $3 \mathrm{p} \mathrm{1/2}$ ) et les fichiers: format.rtf quelque soit le système (Apple ou compatible PC) ou par courrier électronique: revue.laryngologie@wanadoo.fr .

Le texte, une fois accepté par le Comité Scientifique de Lecture et la Rédaction, ne pourra plus être modifié. II doit être présenté de façon parfaite; la correction des épreuves est assurée par la Rédaction. L'auteur est responsable du contenu de son article.

\section{TITRE DE L'ARTICLE, RESUME ET MOTS-CLES}

Le titre de l'article, en français et anglais, indiquera clairement le sujet du travail, suivi du nom des auteurs, du prénom ou de son initiale, ainsi que des titres ou fonctions et de l'origine du travail.

Un résumé (français et anglais) entre 150 et 250 mots, doit obligatoirement accompagner tous les articles et rappeler les objectifs, méthodes, résultats et conclusions du travail présenté. Ne pas oublier les mots clés en français et anglais ( 3 à 5 max).

\section{FI GURES, CLI CHES ET TABLEAUX}

Les éléments fournis, éliminant les photocopies, doivent être de très bonne qualité. L'emplacement des figures dans le texte doit être précisé à l'aide du numéro -exemple: figure 1. La Revue de Laryngologie prend en charge 4 figures et 3 tableaux (les figures et tableaux supplémentaires seront facturés aux auteurs au moment de la première acceptation de l'article par le Comité International de Lecture).

\section{REFERENCES BI BLI OGRAPHI QUES}

Les références bibliographiques complètes (limitées à 25) seront groupées à la fin de l'article. Elles seront indexées et numérotées dans le texte par ordre d'apparition.

Indiquer: nom et initiales des prénoms, titre exact dans la langue originale, nom du journal suivant la nomenclature internationale, année de parution, numéro du tome, les premières et dernières pages. 
Articles: GERSDORFF M, GARIN P. L'endoscopie de l'oreille modifie-t-elle la classification des poches de rétraction et les indications opératoires? Rev Laryngol Otol Rhinol. 1994;115,5:367-368.

Livres: Blayney AW, STACK JP, MCAVOY GJ, RICE HJ. Quantifying healthy ear canal geometry using magnetic resonance imaging. In: M. Portmann Ed. Transplants and implants in otology III. Amsterdam/New York Kugler Publ., 1996: 15-21.

TIRES A PART:

10 tirés à part sont adressés gratuitement aux auteurs ainsi qu'un numéro de la Revue. Le supplément est à leur charge et doit être commandé lors de l'envoi de l'article. 
La hypersensibilité aux substances qu'on inhale et aux aliments dans les troubles d'équilibre corporel

Hypersensitivity to inhalants and food in balance disturbances

Erika Cisi Domingues ${ }^{1}$; Roseli Saraiva Moreira Bittar²; João Ferreira de Mello Junior $^{3}$

${ }^{1} \mathrm{MD}$, PhD post graduation program. Otoneurology Section of the Department of Otorhinolaringology of the School of Medicine of the University of São Paulo, Brazil

2 MD, PhD. Otoneurology Section of the Department of Otorhinolaringology of the School of Medicine of the University of São Paulo, Brazil

3 MD, PhD. Professor. Department of Otorhinolaringology of the School of Medicine of the University of São Paulo, Brazil

Institution:

Hospital das Clínicas of the School of Medicine of the University of São Paulo, São Paulo, Sao Paulo, Brazil

Address for correspondence: Erika Cisi Domingues - Departament of Otorhinolaringology, FMUSP ICHC - Avenida Enéas de Carvalho Aguiar 255, $6^{\circ}$ andar -Sala 6021 - São Paulo / SP - Brasil - CEP: 05403-000 - E-mail: erikacisi@globo.com 


\section{RESUME}

\section{La hypersensibilité aux substances qu'on inhale et aux aliments dans les troubles d'équilibre corporel}

Introduction: la prévalence d'allergie dans les patients avec la maladie de Ménière a été stabilisée autour de 41,6\% pour les substances qu’on inhale et 26,6\% pour les aliments, qui sont des numéros très élevés par rapport la prévalence d’allergie dans la population en général. Ces numéros varient entre $9 \%$ et $30 \%$ pour les substances qu’on inhale (au Brésil) et pour les aliments la variation est de 1\% a 3\%. Objectifs: évaluer la prévalence de la hypersensibilité type I pour les substances qu’on inhale et pour les aliments dans la population du secteur d'otoneurologie du Hôpital des Cliniques de la Faculté de Médicine de São Paulo et décrire les symptômes vestibulaires chez ces patients. Méthode: soixante-quinze patients avec des troubles d’équilibre d’origine périphérique ont été soumis a un interrogatoire pour caractériser les symptômes cochléo-vestibulaires. Ils on été soumis aussi a un test cutané (prick test) pour 13 substances qu'on inhale pour 5 aliments. Résultats: vingt-cinq (33,3\%) patients ont présenté le prick test positif pour les substances qu’on inhale. Pour les aliments le prick test a été positif dans 6 (8\%) patients. Quatre patients ont présenté prick test positif alors qu'ils n'avaient pas des symptômes allergiques. Le vertige avait la même proportion entre les patients avec prick test positif et négatif. Conclusion: la prévalence des réactions de la hypersensibilité type I aux substances qu'on inhale et aux aliments dans la population évaluée a été majeur qu'entre la population en géneral. Les symptômes vestibulaires n'avaient pas de différence entre les patients avec prick test positif ou négatif. Toutefois, on doit obtenir un numéro plus grand d'échantillon pour que les informations soient assurées.

Mots-clés : vertige, acouphène, hypersensibilité immédiat 


\section{ABSTRACT}

Introduction: The prevalence of allergy in patients with Meniere's disease was established as approximately $41.6 \%$ for inhalants and $26.6 \%$ for food. These are elevated values in relation to the prevalence of allergy in the general population, which varies from $9 \%$ to $30 \%$ for inhalants (in Brazil) and from $1 \%$ to $3 \%$ for food. Objectives: To evaluate the prevalence of type I hypersensitivity reactions to inhalants and food in the patients of the Neurotology Sector of the 'Hospital das Clinicas' of the University of São Paulo Medical School and to describe vestibular symptoms of these patients. Method: Seventy-five patients with imbalance due to peripheral origin were evaluated by a questionnaire for the clinical characterization of the cochleo-vestibular symptoms and underwent the prick test for 13 inhalants and 5 food stuffs. Results: twenty-five (33.3\%) patients presented positive prick tests to at least one inhalant allergen and $6(8 \%)$ of them to at least one food allergen. Four patients presented positive prick tests without allergy symptoms. The prevalence of the complaint of rotatory dizziness was similar among the patients with positive and negative prick tests. Conclusion: the prevalence of type I hypersensitivity reactions to inhalants and food in the population evaluated was greater than in the general population. The vestibular symptoms did not differ among the patients with either positive or negative prick tests. However, a larger sample size should be obtained for the data to be more reliable.

KEY WORDS: dizziness, tinnitus, immediate hypersensitivity 


\section{INTRODUCTION}

Hypersensitivity reactions have been associated with imbalance, especially regarding Meniere's disease. In 1923, Duke was the first author to relate allergy to Meniere's disease when he observed the reactivation of vestibular symptoms after provocation tests with allergens to which the patients were sensitive and a clinical improvement with the use of epinephrine (1).

In the 70's decade, several authors described clinical improvement of vertigo, tinnitus and hypoacusis after specific treatment for allergies from inhalants and food $(2,3,4,5)$. Since then, the endolymphatic sac has been recognized as the "site of immune reactions in the inner ear” $(6,7,8)$, due to its capacity to process antigens and produce its proper immunoresponse to antibodies. The endolymphatic sac has a high vascular sub epithelial space rich in fenestrated blood vessels, permeable to several substances in the inner ear, some of them considered antigens (9). The idea became attractive when high levels of immuno-complexes were detected in patients with Meniere's disease $(10,11)$.

There are four immuno-allergic reactions: type I (immediate hypersensitivity reaction, mediated by IgE); type II (hypersensitivity reaction mediated by class IgG antibodies); type III (reaction by circulatory immuno-complexes) and type IV (delayed hypersensitivity reaction mediated by sensitive T-lymphocytes) (12). Some specific clinical characteristics of Meniere's disease suggest autoimmune origin, as the following: bilateral in some cases, reactivating after long periods of remission, development of the disease in the normal ear after trauma or infection of the contra-lateral ear. Observation further shows a temporal relation between the 
Meniere crisis and climatic variations and/or contact with known inhalant allergens or food ingestion (13). Recently, the prevalence of allergy in patients with Meniere's disease was estimated as approximately $41.6 \%$ for inhalants and $26.6 \%$ for food (14), an elevated percentage in relation to data from the general population.

The population prevalence of allergy for inhalants in Brazil varies from $25 \%$ $30 \%$ (15) to $9 \%$ (16). The prevalence for food in general population is estimated at from $1 \%$ to $3 \%(17)$.

With the high prevalence of both dizziness as well as allergy, it is to our interest to investigate the inter-relationship between the two. Although Meniere's disease has been the principal focus of studies developed up to now, it is important to know if its prevalence with allergy is the same as the other neurotological diagnoses.

There are no data describing the national prevalence of allergy in a population with balance disorders. These findings would open up new opportunities for a therapeutic approach. Once these individuals are identified, the documentation of their specific symptoms could help us to identify the endolymphatic hydrops.

\section{OBJECTIVES}

The objective of this study is to determine the prevalence of immediate hypersensitivity reactions (type I) to inhalants and food in a population of patients with balance disturbances and to describe their symptoms.

\section{METHOD}

This study design is a transversal cut of the patients from the Neurotological 
Sector of the ENT Department of the University of São Paulo Medical School. The project was approved by the Ethics Committee for the Analysis of Research Projects (protocol no. 867/03) of this hospital. All the patients invited to participate received clarifying orientation and signed a consent form.

The data described represent the results of an investigation of individuals with dizziness complaints and tested positive in allergy exams. All the individuals included in the study had alterations suggestive of peripheral disease, excluding those that represented balance problems of central origin.

For the topographical diagnosis of the vestibular lesion, patients underwent complete anamnesis, with characterization of the type of dizziness and its relation to cochlear and/or systemic symptoms. Blood exams (hemogram, fasting glycemia, serology for lues, lipidic profile, thyroid hormone dosage and, if necessary, glycemic and insulinemic curves) were requested along with tonal and vocal hearing test with impedance test and reflex tympanometry and electronystagmography. The electrocochleography and image exams requested were according to the specific clinical indication.

After identification, the individuals with peripheral disorders responded to a questionnaire for the characterization of the type of dizziness (vertigo, lightheadedness, disequilibrium, floating sensation, visual dimness, falling sensation and lateropulsion), tinnitus frequency (high or low frequencies or both). All individuals were asked to regard to some individual sensitivity to food or inhalants. Prick tests for 18 allergens (house dust, dust mites, aerofungi, gramineous plant, flowers, cat epithelium, dog epithelium, feathers, cotton, grass (Dactylis glomerata), macela 
(Achyrocline satureioides), cockroach, pyrethrum, gluten, corn, wheat, soy and peanut) were carried out. The allergens were chosen in accordance with their clinical relevance inherent to São Paulo city, those most frequently responsible for allergic reactions in Brazil (18). A cutaneous papule response equal to or greater than three millimetres was considered positive.

The variables considered were age, gender, positive test result (and the allergen responsible for the positive reaction), clinical type of dizziness and tinnitus. For the statistical evaluation of the results, the chi-squared test and the student's t-test were used for the two independent samples. A 5\% significance level was adopted.

\section{RESULTS}

Seventy-five patients, with peripheral balance disorders, were included in the study. Seventy-six percent of the individuals in the sample were female. The age varied from 18 to 74 years, with an average of 50.4 years (standard deviation: 13.375).

Analyzing the sample studied, 25 individuals (33.3\%) [CI (95\%) $=22.9 \%$ to 45.2\%] were positive in the prick tests for at least one of the thirteen inhalant allergens tested: house dust (88\%) and dust mites (80\%) were the allergens that provoked the highest percentage of positive responses, followed by cat epithelium (44\%), dog epithelium (40\%), cockroach (36\%), feathers (12\%), cotton (12\%) and grass (Dactylis glomerata) (12\%). To a lesser degree pyrethrum, aerofungi and macela (Achyrocline satureioides) were $8 \%$ positive and the others (gramineous plant and flowers) 4\%. In relation to the food allergens tested, only 6 patients (8\%) 
[CI $(95 \%)=3.0 \%$ to $16.6 \%$ ] had positive reactions to at least one allergen. The most frequent was corn (20\%), followed by gluten (8\%), soy (8\%), peanut (8\%) and wheat (4\%). All the patients were positive to food allergens also reacted to at least one inhalant allergen. There was no difference between men and women in positive responses to the prick tests $(\mathrm{p}=0.390)$. It was significant that we observed that the individuals who were positive for allergens in the prick test tended to be younger than those who were negative $(p=0.029)$. Some patients referred to symptoms (urticaria, dysphonia, gastric colic or diarrhea) as a consequence of food that does not involve part of the bacteria utilized (milk, mayonnaise, beef, pork, hot dogs, sardines, shrimp, oatmeal, coffee, manioc, watercress, mango and pineapple). The prevalence of type I hypersensitivity to at least one of the allergens used was 33.3\% of the total. All the patients of this percentage reacted to at least one inhalant and $8 \%$ of them also responded to least one food antigen.

The majority of patients evaluated had two or more different types of dizziness. Among the 25 individuals who were positive for the prick tests, 22 (88\%) had rotatory dizziness, 10 (40\%) referred to light-headedness, 5 (20\%) disequilibrium, 7 (28\%) floating sensation, 3 (12\%) visual dimness, 1 (4\%) falling sensation and 1 (4\%) lateropulsion. Among the 50 individuals who were negative for the prick test, 38 (76\%) had rotatory dizziness, 15 (30\%) light-headedness, 18 (36\%) disequilibrium, 11 (22\%) floating sensation, 10 (20\%) visual dimness, 9 (18\%), falling sensation and 7 (14\%) lateropulsion. There was no statistically significant difference as to the distribution of the different clinical profiles of the characterization of dizziness (Table 1). 
Tinnitus was present in 21 (84\%) of the 25 patients with positive allergy tests. In relation to the 50 patients with negative allergy tests, tinnitus was present in 44 (88\%) of the cases. In regard to the presence of tinnitus, once again there was no statistically significant difference between the two groups $(p=0.326)$. The tinnitus was related by different frequencies (Table 2).

In 8 (38.1\%) of the 21 patients with positive prick tests and tinnitus, there was the report of intensification of the symptom during the dizzy spells, the same occurring in 15 (34.1\%) of the 44 patients with negative prick tests and tinnitus. Again, there was not statistically significant difference between the two groups $(\mathrm{p}=0.787)$.

\section{DISCUSSION}

In our sample, the value found of $8 \%$ for the prevalence of hypersensitivity to food is greater than that of the $1 \%-3 \%$ described in the general population (17) although both values are within the CI of $95 \%$ (3.0 to $16.6 \%$ ), which is wide, since our sample is relatively small for an evaluation of prevalence. The data obtained suggest a relation between the reactions of hypersensitivity to food and the vestibular disturbances, according to reports in the literature $(1,3,4,5,13,14,19,20)$. We should consider further that the values obtained can be underestimated for four reasons: [1] there are different types of reactions that originate the response to food (type I, III and IV of Gell and Coombs) and reactions types III and IV cannot be evaluated by the prick test (21); [2] a small number of allergens were used in the prick test; [3] some individuals were in reference to sensitivity to allergens not tested in this study 
and [4] the negative result did not exclude food hypersensitivity since the via of antigenic percutaneous stimulation differs from that of oral stimulation.

Up to the present time, a precise method for diagnosing food reactions has not been established. There are some test proposals; however they all have some pros and cons. Among these tests are that of a daily ingestion of food and a description of the symptoms perceived (22); in vitro tests of the releasing of histamine and the cytotoxic test of leukocytes. The problem with the in vitro tests is the necessity of correlation between the findings and the symptoms observed, a subjective evaluation. Tests of oral provocation are considered the gold standard for food reactions (23), although they are not safe due to the risk of an anaphylactic reaction.

In relation to the findings of prevalence to hypersensitivity to inhalants, the prevalence we found of $33.3 \%$ in the population studied seems to be greater than that of the general population $(15,16)$, suggesting an inter-relation between allergy and vestibular disorders. However, two points must be clarified. The study of ISAAC (International Study of Asthma and Allergies) was done only with children and did not differentiate inflammatory from infectious rhinitis and therefore, the value approximate found of 30\% could be overestimated (15). In talking about the AILA, that evaluated the prevalence of allergy in Latin America and found a value of $9 \%$ in Brazil, there had been no specific protocol for the diagnosis of allergic rhinitis and the value found could have been underestimated (16). Considering the two studies available, we can infer an average theoretical value of approximately 15\% (24) for the prevalence of allergic rhinitis in the general population. As such, the prevalence of hypersensitivity to inhalants in the population studied with peripheral vestibulopathy of $33.3 \%$ was greater than the $15 \%$ expected. 
Our results were calculated based on the positive results of the prick tests, whose predictive positive value (ppv) for allergic rhinitis is $48.7 \%$ (25). Thus, approximately $50 \%$ of the positive tests may not signify disease (allergic rhinitis), which leads us to a prevalence of something around $15 \%$ in the population studied. If half of the sample studied has sensitivity to inhalants without, however, presenting allergic rhinitis, the question is whether dizziness could be a still unknown manifestation of atopy such as rhinitis, asthma and atopic dermatitis. In order to confirm this hypothesis, it would be interesting to apply the antigenic provocation test to these patients.

In relation to the symptoms, vertigo was the most common complaint of dizziness among the patients with positive or negative prick tests, a fact that does not permit us to associate the allergic reactions to hydrops. The concomitance of tinnitus and dizziness in similar proportions in the two groups also does not permit us to associate the symptoms to Meniere's disease. To do so, we could propose a research model of submitting patients to antigenic provocation tests and electrocochleography.

It is interesting to note that four patients with positive prick tests were not in reference to allergy symptoms in the anamnesis. It suggests us that we can be dealing with "sensitivized" individuals by means of an atopic syndrome not yet established: peripheral vestibulopathy.

In spite of all this discussion, the sample of the present study is too small for obtaining more reliable data of prevalence. These data for prevalence are fundamental, since criteria for evaluation, investigation and treatment of disease only 
can be established if we know the manner in which they are manifested in the populations. 


\section{BIBLIOGRAPHIC REFERENCES}

1. DUKE WW. Ménière's syndrome caused by allergy. JAMA. 1923; 81(26):217981.

2. McCABE BF. Autoimmune Sensorineural Hearing Loss. Ann Otol Rhinol Laryngol. 1979; 88:585-89.

3. WILSON WW. Antigenic excitation in Ménière's disease. Laryngoscope. 1972; 82:1726-35.

4. SHAVER Jr EF. Allergic management of Ménière's disease. Arch Otolaryngol. 1975; 101(2):96-9.

5. ENDICOTT JN, STUCKER FJ. Allergy in Ménière's disease related fluctuating hearing loss preliminary findings in a double-blind crossover clinical study. Laryngoscope. 1977; 87:1650-57.

6. RASK-ANDERSEN $\mathrm{H}$, STAHLE J. Immunodefense of the inner ear? Lymphocyte-macrophage interaction in the endolymphatic sac. Acta Otolaryngol (Stockh). 1980; 89:283-94.

7. HARRIS JP. Immunology of the inner ear: evidence of local antibody production. Ann Otol Rhinol Laryngol. 1984; 93:157-62.

8. TOMIYAMA S, HARRIS JP. The role of the endolymphatic sac in inner ear immunity. Acta Otolaryngol. 1987; 103:182-8.

9. ALTERMATT HJ, GEBBERS JO, MULLER C, ARNOLD W, LAISSUE JA. Human endolymphatic sac: evidence for a role in inner ear immune defense. ORL J Otorhinolaryngol Relat Spec. 1990; 52:143-8. 
10. BROOKES GB. Circulating immune complexes in Ménière's disease. Arch Otolaryngol Head Neck Surg. 1986; 112:536-40.

11. DEREBERY MJ, SRINAVASA RV, SIGLOCK TJ, LINTHICUM FH, NELSON RA. Ménière's disease: an immune complex-mediated illness? Laryngoscope. 1991; 101:225-9.

12. GELL PGH, COOMBS RRA, eds. Clinical Aspects of Immunology. 1st ed. Oxford, England: Blackwell; 1963.

13. DEREBEY MJ. The role of allergy in Ménière's disease. Otolaryngologic Clinics of North America. 1997; 30(6):1007-17.

14. DEREBERY MJ, BERLINER KI. Prevalence of allergy in Ménière's disease. Otolaryngology-Head and Neck Surgery. 2000; 123(1):69-75.

15. SOLÉ D, WANDALSEN GF, CAMELO-NUNES IC, NASPITZ CK, ISAAC BRAZILIAN GROUP. Prevalence of symptoms of asthma, rhinitis and atopic eczema among Brazilian children and adolescents identified by the International Study of Asthma and Allergies (ISAAC) - phase 3. J. Pediatr. (Rio J.). 2006; 82 (5): 341-46.

16. AILA (Allergies in Latino America). Multinational research in patients with allergic rhinitis in Latin America. Results presented in XIX the World-wide Congress of Otorrinolaringologia in São Paulo, Brazil, June, 2009.

17. BJÖRKSTÉN B. The epidemiology of food allergy. Curr Opin Allergy Clin Immunol. 2001; 1: 225-7.

18. II CONSENSO BRASILEIRO SOBRE RINITES 2006. Revista Brasileira de Alergia e Imunopatologia, 2006; 29(1): 29-58. 
19. DEREBERY MJ; VALENZUELA S. Meniere's syndrome and allergy. Otolaryngol Clin North Am, 1992; 25(1): 213-24.

20. DEREBERY, M.J. Allergic and immunologic aspects of Meniere's disease. Otolaryngol head Neck Surg 1996; 114: 360-5.

21. TIPTON, WR. Evaluation of skin testing in the diagnosis of IgE-mediated disease.Pediatric Clin North Am. 1983; 30: 785-93.

22. CLARKE L, McQUEEN J, SAMILD A, SWAIN AR. "Dietitians Association oj Australia review paper. The dietary management of food allergy and food intolerance in children and adults”. Aust J Nutr Dietetics. 1996; 53 (3): 89-98.

23. SICHERER SH. Food allergy: when and how to perform oral food challenges. Pediatr Allergy Immunol. 1999; 10:226-34.

24. MELLO JR, JF. Personal communication in 12/09/2009.

25. TSCHOPP JM, SISTEK D, SCHINDLER C, LEUENBERGER P, PERRUCHOUD AP, WÜTHRICH B, BRUTSCHE M, ZELLWEGER JP, KARRER W, BRÄNDLI O, SAPALDIA team. Current allergic asthma and rhinitis: diagnostic efficiency of three commonly used atopic markers (IgE, skin prick tests, and Phadiatop). Results from 8329 randomized adults from the SAPALDIA study. Allergy 1998; 53 (6): 608-613. 
Table 1 - Distribution of the various types of dizziness in patients with positive and negative prick tests.

\begin{tabular}{|l|c|c|c|}
\hline \multicolumn{1}{|c|}{ TYPE OF DIZZINESS } & PRICK TEST & PRICK TEST & $p$ \\
& POSITIVE & NEGATIVE & $\mathbf{n}=\mathbf{n}$ =75 \\
\hline Rotatory & $22(88 \%)$ & $38(76 \%)$ & 0.358 \\
\hline Light-headedness & $10(40 \%)$ & $15(30 \%)$ & 0.544 \\
\hline Disequilibrium & $5(20 \%)$ & $18(36 \%)$ & 0.250 \\
\hline Floating sensation & $7(28 \%)$ & $11(22 \%)$ & 0.774 \\
\hline Visual dimness & $3(12 \%)$ & $10(20 \%)$ & 0.590 \\
\hline Falling sensation & $1(4 \%)$ & $9(18 \%)$ & 0.186 \\
\hline Lateropulsion & & & 0.355 \\
\hline
\end{tabular}

$p$ : value of the chi-squared test with Yates correlation; $\mathrm{n}=$ number of patients 
Table 2 - Distribution of patients with tinnitus in accordance to frequency variation and to response on the prick test.

\begin{tabular}{|l|c|c|}
\hline \multicolumn{1}{|c|}{ TYPE OF TINNITUS } & PRICK TEST & $\begin{array}{c}\text { PRICK TEST } \\
\text { NEGATIVE }\end{array}$ \\
& $\mathbf{n = 2 1}$ & $\mathbf{n = 4 4}$ \\
\hline High frequency & $7(33.3 \%)$ & $23(52.27 \%)$ \\
\hline Low frequency & $7(33.3 \%)$ & $9(20.45 \%)$ \\
\hline Mixed & $7(33.3 \%)$ & $12(27.27 \%)$ \\
\hline
\end{tabular}

n: number of patients with tinnitus 
1 INTRODUÇÃO 
A tontura é a terceira queixa mais comum na prática clínica, e acomete mais de um terço das pessoas em alguma época da vida (Kroenke et al., 1989). Cerca de 90\% dos indivíduos com mais de 65 anos já procurou serviço médico com tontura, ao menos uma vez durante a vida. (Goebel, 2000).

Até pouco tempo atrás, o tratamento proposto para os distúrbios do equilíbrio corporal tinha, essencialmente, como objetivo a diminuição da sintomatologia, em função da compreensão limitada de sua fisiopatologia e da dificuldade em se determinar um diagnóstico etiológico adequado. Desde então, muitos estudos são feitos para desvendar os diversos mecanismos que podem acometer o labirinto, dentre eles, os mecanismos imunoalérgicos.

A relação entre reações de hipersensibilidade a alérgenos e os distúrbios do equilíbrio corporal vem sendo alvo de inúmeros questionamentos e pesquisas. A Doença de Ménière (DM) é a síndrome vestibular associada com maior frequência às reações imunoalérgicas (Williams, 1952; Seymor, 1954; Shaver, 1975; Endicott, 1977; Brookes, 1986; Latkowski, 1987; Miyamura et al., 1987; Hsu et al., 1990; Derebery et al., 1991; Derebery, Valenzuela, 1992; Uno et al., 1992; Viscomi, Bojrab, 1992; Derebery, 1997; Derebery, Berliner, 1998; Gibbs et al., 1999; Derebery, 2000a, 2000b; Noell et al., 2001; Kelles et al., 2004; Derebery, Berliner, 2007).

Existem quatro tipos de mecanismos de reações imunoalérgicas descritas por Gell e Coombs (1963): 
- TIPO I: reação de hipersensibilidade imediata, mediada por imunoglobulina E (IgE). No organismo previamente sensibilizado, o alérgeno liga-se à IgE específica aderente à superfície dos mastócitos. Ocorre a degranulação e liberação de citocinas (histamina, bradicinia, serotonina), que desencadeiam a reação de hipersensibilidade em poucos minutos;

- TIPO II: reação de hipersensibilidade mediada por anticorpo da classe imunoglobulina G (IgG). É conseqüente à interação antígeno-anticorpo na superfície da célula-alvo, que é então fagocitada por macrófagos;

- TIPO III: reação por imunocomplexos (antígeno-anticorpo) circulantes que se depositam em tecidos-alvos, e resultam em resposta inflamatória local ou geral;

- TIPO IV: reação de hipersensibilidade tardia (24 a 48 horas após contato com o alérgeno), mediada por linfócitos T sensibilizados que, mediante a liberação de linfocinas, estimulam a migração local de células mononucleares inespecíficas que desencadeiam a cascata da reação imune.

Em 1923, Duke foi o primeiro autor que relacionou alergia com DM, quando observou melhora clínica da queixa de tontura de seus pacientes com o uso de epinefrina. Por outro lado, observou ainda a reativação dos sintomas vestibulares após testes de provocação com alérgenos a que eram sensíveis. Na década de 70 a idéia foi fortalecida com o surgimento do conceito de autoimunidade nos distúrbios cócleo-vestibulares (McCabe, 1979). Ainda na mesma década, vários autores descreveram melhora clínica da vertigem, do zumbido e da hipoacusia com terapias de dessensibilização a alérgenos inalantes e alimentares (Powers, 1973; Pulec, House, 1973; Wilson, 1972; Shaver, 1975; Endicott, Stucker, 1977). 
A partir da década de 80, surgiram vários estudos a respeito do saco endolinfático como "local das reações imunes da orelha interna” (Rask-Andersen, Stahle, 1980; Harris, 1984; Tomiyama, Harris, 1987). Esta teoria leva em conta a capacidade que o saco endolinfático possui de processar antígenos e produzir sua própria resposta imune por anticorpos. Sua rede vascular fenestrada rica apresenta permeabilidade seletiva à circulação de determinadas substâncias na orelha interna e permite a entrada de antígenos (Altermatt et al., 1990). Nessa mesma ocasião, alguns autores detectaram níveis elevados de imunocomplexos circulantes em pacientes com DM (Brookes, 1986; Hsu et al., 1990; Derebery et al., 1991).

Derebery (1997) aponta algumas características clínicas sugestivas de causa autoimune para certos casos de DM, como bilateralidade da doença, evolução em crises, e desenvolvimento da doença em orelha normal após trauma ou infecção em orelha contra-lateral. A autora também infere uma provável causa alérgica para a hidropisia, fundamentada na observação da relação temporal entre as crises e variações climáticas e/ou contato com alérgenos inalantes conhecidos, ou ainda com a ingestão de alimentos específicos. Recentemente, a prevalência de alergia em pacientes com DM a inalantes foi estimada em torno de $41,6 \%$ e a alimentos em cerca de 26,6\%, porcentuais elevados em relação aos dados populacionais (Derebery, Berliner, 2000). Mesmo considerando-se a elevação de sua porcentagem relativa, a prevalência populacional de alergia no Brasil, varia de 25\% a 30\% (Sole et al., 2006) a 9\% (Allergies in Latino-America - AILA, 2009) para inalantes. Na população em geral a prevalência de alergia para alimentos é estimada em torno de $1 \%$ a $3 \%$ (Björkstén, 2001).

Diante da alta prevalência populacional tanto para a tontura como a alergia, é 
nosso interesse investigar a inter-relação entre as duas. Embora a DM seja o foco principal dos estudos desenvolvidos até então, também é importante saber se ela apresenta a mesma prevalência de alergia quando comparada a outros diagnósticos otoneurológicos. Não existem dados referentes à prevalência de casos de alergia no território nacional, em uma população portadora de distúrbios do equilíbrio corporal, para que possamos responder essa questão. A identificação desses indivíduos traria novas possibilidades terapêuticas. Uma vez identificados, é também importante determinar a presença de sintomatologia específica, relacionada ou não à hidropisia endolinfática. 
2 OBJETIVOS 
Avaliar a prevalência de reações de hipersensibilidade tipo I a inalantes e a alimentos, na população de pacientes do ambulatório do setor de Otoneurologia do Departamento de Otorrinolaringologia do Hospital das Clínicas da Faculdade de Medicina da Universidade de São Paulo (HC-FMUSP).

Descrever os sintomas vestibulares nos pacientes com hipersensibilidade tipo I a inalantes e a alimentos. 
3 REVISÃO DE LITERATURA 
Cada vez mais a alergia é considerada como causa de alguns distúrbios do equilíbrio corporal, especialmente na DM, descrita pela primeira vez por Prósper Ménière, em 1861.

A primeira descrição da provável relação entre alergia e tontura data de 1923, quando Duke relata melhora clínica da tontura de seus pacientes alérgicos com aplicação de epinefrina. Esses mesmos indivíduos relatavam piora dos sintomas vestíbulo-cocleares com testes de provocação antigênica com os alérgenos aos quais eram sensíveis (Duke, 1923).

A partir da década de 20, vários outros pesquisadores apresentam evidências clínicas que sugerem que a alergia seja um dos fatores etiológicos das labirintopatias. Existem descrições de pacientes com tontura (DM) e alergia que melhoram dos sintomas vestibulares após o tratamento do processo alérgico (Shaver, 1975; Endicott, Stucker, 1977; Latkowski, 1987; Derebery, 1997, 1998, 2000a,). Wilson (1972) relata a presença de vertigem em seus pacientes quando submetidos a testes de provocação antigênica e que melhoram com terapias de dessensibilização. Apoiado nessas observações, Wilson propõe a alteração da homeostase na circulação sanguínea da orelha interna por estimulação antigênica. Para Derebery (1996), na presença de estímulo antigênico o paciente não apresenta melhora dos sintomas labirínticos enquanto os antígenos (inalantes ou alimentares) não são reconhecidos e abordados terapeuticamente.

Existem ainda outras evidências que relacionam a alergia com a tontura (mais 
especificamente a DM), como a presença da histamina encontrada em quantidade suficientemente tóxica na estria vascular. A histamina é capaz de provocar vasodilatação local e poderia ser o “ponto gatilho” da hidropisia endolinfática (Williams, 1952; Seymor, 1954).

Com o surgimento do conceito de autoimunidade relacionada aos distúrbios cócleo-vestibulares, proposto por McCabe (1979), a DM passa a ser considerada, por alguns autores, como uma decorrência de afecções autoimunes e/ou inflamatórias (Hughes et al., 1988; Rauch et al., 1995; Alleman et al., 1997), alérgicas (Derebery, 1996) ou virais (Bergström et al., 1992). Assim sendo, alguns estudos identificam o saco endolinfático como o sítio das reações imunes da orelha interna (Harris, 1984; Tomiyama, Harris, 1987; Rask-Andersen, Stahle, 1980). Sua rede vascular rica e fenestrada apresenta permeabilidade seletiva à circulação de determinadas substâncias na orelha interna, observando-se, ainda, sua capacidade de processar antígenos e produzir sua própria resposta imune por anticorpos (Altermatt et al., 1990).

Alguns autores destacam algumas características eventuais da DM que poderiam sugerir uma causa autoimune ou alérgica, como: bilateralidade da doença, evolução em crises, doença em orelha normal após trauma ou infecção em orelha contralateral, relação temporal das crises com mudança climática ou contatos com alérgenos conhecidos (alimentos ou inalantes), história de alergia e falha ao tratamento usual para DM (Derebery, Valenzuela, 1992; Derebery, 1997).

Existem autores que sugerem uma reação alérgica tipo I como responsável por hidropisia endolinfática transitória. A introdução de antígenos na orelha média de cobaias, previamente sensibilizadas, foi capaz de provocar hidropisia endolinfática 
com degranulação de mastócitos e infiltrado de eosinófilos na orelha interna, sugerindo mediação por IgE sérica (Miyamura et al., 1987; Uno et al., 1992). Na mesma época, Hsu et al. (1990) não encontram diferença estatisticamente significante da dosagem de IgE sérica em pacientes com DM e o grupo controle. No entanto, Keles et al. (2004) descrevem níveis elevados de IgE sérica total em 41,3\% de seus pacientes com DM contra 19,5\% dos pacientes do grupo controle.

Outros autores descrevem níveis elevados de imunocomplexos circulantes (ICC) em pacientes com DM (Brookes, 1986; Hsu et al., 1990; Derebery et al., 1991; Derebery, Berliner, 2007), achado sugestivo de reação alérgica tipo III (mediada por ICC) na patogênese da hidropisia endolinfática (Brookes, 1986).

Na literatura também é descrito o aumento da relação entre potencial de somação e potencial de ação na eletrococleografia (ECoG), após provocação antigênica em pacientes com DM (Viscomi, Bojrab, 1992; Gibbs et al., 1999). Noell et al. (2001) defendem o uso da ECoG para documentar alterações na orelha interna após estimulação intranasal com alérgenos, em pacientes com DM e alergia a inalantes. Entretanto, Eaton et al. (2003) questionam o uso da ECoG para predizer sintomas cócleo-vestibulares uma vez que alguns pacientes com DM, apresentam alterações da relação potencial de somação/potencial de ação, após provocação antigênica intranasal sem, no entanto, apresentar sintomas cócleo-vestibulares.

Recentemente, Derebery e Berliner (2007) relataram que a positividade dos testes alérgicos (cutâneo ou in vitro), assim como elevados níveis séricos de imunocomplexos circulantes (ICC), linfócitos CD4 e de outros componentes imunológicos, são mais frequentes em pacientes com DM em relação ao grupo controle. Além disso, os autores reforçam o bom efeito da imunoterapia nos sintomas 
otoneurológicos dos pacientes com DM e alergia. Os mesmos autores relatam dados de prevalência de $41,6 \%$ de alergia a inalantes e de $26,6 \%$ de alergia a alimentos em pacientes com DM (Derebery, Berliner, 2000).

Na América Latina, contamos com alguns estudos nos quais foi estimada a prevalência de alergia. O ISAAC (International Study of Asthma and Allergies in Childhood, 1998) foi realizado mediante a aplicação de questionários direcionados a crianças e adolescentes. Os questionários abordam sintomas de atopia (asma, rinite, dermatite atópica) em centros habilitados de várias cidades, em diferentes países, incluindo o Brasil. No estudo ISAAC, com relação à rinite, foram pesquisados apenas sintomas de rinite inflamatória não infecciosa, independente de terem sido causados por contato com antígenos (atopia) ou apenas irritantes inespecíficos. Recentemente, foram apresentados no XIX Congresso Mundial de Otorrinolaringologia, em São Paulo, Brasil (2009), os resultados de uma pesquisa multicêntrica (Allergies in Latino-America - AILA, 2009), realizada por meio de entrevista, em que foram avaliados 21.626 pacientes em oito países latinoamericanos, entre eles o Brasil, dos quais 1088 adultos e 457 crianças apresentavam diagnóstico de rinite alérgica (AILA, 2009). Os resultados das pesquisas apresentam prevalências variáveis, estimadas entre 9\% (AILA, 2009) e 30\% (Solé et al., 2006) para o Brasil.

Estima-se que a prevalência de alergias alimentares seja de aproximadamente 1-3\% da população de adultos e de 4-6\% entre crianças (Björkstén, 2001). Entretanto, até o presente momento, não há nenhum estudo de abrangência nacional ou internacional, como o ISAAC, que tenha sido realizado para avaliar a real dimensão da alergia alimentar em populações ao redor do mundo. Na maioria das vezes, os 
dados de prevalência ou incidência de alergia alimentar são obtidos com o estudo de pequenos grupos populacionais, de risco ou não, com metodologia diagnóstica variável e, em geral, com resultados não extrapoláveis (Solé et al., 2007). 
4 CASUÍSTICA E MÉTODO 
Este estudo configura um corte transversal da análise de pacientes do Ambulatório de Otoneurologia do Departamento de Otorrinolaringologia do Hospital das Clínicas da Faculdade de Medicina da Universidade de São Paulo (HCFMUSP). Foi aprovado pela Comissão de Ética para Análise de Projetos de Pesquisa do Hospital das Clínicas da Faculdade de Medicina da USP sob o número de protocolo 867/03. (Apêndice)

\subsection{Casuística}

Os indivíduos alocados para o estudo foram previamente avaliados por meio da rotina ambulatorial do Setor de Otoneurologia do Departamento de Otorrinolaringologia do HCFMUSP para caracterização do distúrbio vestibular apresentado. A avaliação compreendeu anamnese; pesquisa dos pares cranianos; audiometria tonal, vocal e impedanciometria; pesquisa laboratorial de hormônios tireoideanos, colesterol total e frações, glicemia de jejum, hemograma e reações sorológicas para sífilis (RSS); exame eletronistagmográfico compreendendo o estudo da oculomotricidade, pesquisa do nistagmo espontâneo, nistagmos posicionais e testes calóricos com estimulação a água a $30^{\circ} \mathrm{C}$ e $44^{0} \mathrm{C}$. Quando necessário, foram solicitados a curva glicêmica de 3 horas com insulinemia, potenciais evocados e exames radiológicos para complementação diagnóstica, 
Após investigação e caracterização da vestibulopatia apresentada, os indivíduos participantes foram selecionados a partir de critérios de inclusão e exclusão.

\subsubsection{Critérios de inclusão}

- alterações otoneurológicas sugestivas de disfunção vestibular periférica;

- assinatura do Termo de Consentimento Livre e Esclarecido.

\subsubsection{Critérios de exclusão}

- alterações otoneurológicas sugestivas de disfunção vestibular central.

\subsection{Método}

Após definição do distúrbio vestibular apresentado, os pacientes foram incluídos de maneira consecutiva, desde que fossem obedecidos os critérios de inclusão e exclusão.

\subsubsection{Caracterização clínica}

\subsubsection{Do equilíbrio}

Os pacientes foram submetidos a um questionário para caracterização clínica de tontura, audição e/ou zumbido, segundo proposta descrita no Anexo A. 


\subsubsection{Da alergia}

Foi aplicado um questionário de sintomatologia alérgica a inalantes e alimentos conforme Anexo B.

\subsubsection{Teste alérgico}

Após a caracterização clínica, os indivíduos participantes do projeto foram submetidos a teste cutâneo (prick test) para 18 alérgenos: 13 inalantes e 5 alimentares (Tabela 1). Os alérgenos foram escolhidos de acordo com a relevância clínica inerente à cidade de São Paulo, e a maioria citada como os mais frequentes responsáveis pelo desencadeamento de reações alérgicas no Brasil (Solé et al., 2006a; Solé et al., 2008).

Tabela 1. Alérgenos testados nos pacientes participantes do presente estudo

\begin{tabular}{l|l}
\hline \hline Alérgenos inalantes & Alérgenos alimentares \\
\hline ácaro & amendoim \\
algodão & glúten \\
barata & milho \\
capim & soja \\
epitélio de cão & trigo \\
epitélio de gato & \\
flor & \\
fungos do ar & \\
gramínea & \\
macela & \\
pena & \\
piretro & \\
poeira domiciliar & \\
\hline \hline
\end{tabular}




\subsubsection{Aplicação do teste}

Após a antissepsia da pele com algodão embebido em álcool a $70^{\circ}$, os extratos antigênicos foram sequencialmente gotejados no antebraço de cada paciente com espaços de 2,0cm. Foram ainda utilizados, o controle positivo (histamina) e negativo (solução salina). Após o gotejamento, foi feita a punctura da pele sob cada solução e realizada a leitura do teste após 20 minutos. Considerou-se como resposta positiva o surgimento de pápula cutânea maior ou igual a três milímetros.

\subsubsection{Variáveis analisadas}

Para análise, foram consideradas as seguintes variáveis qualitativas e quantitativas:

- idade;

- gênero;

- positividade do teste;

- $\quad$ alérgeno responsável pela reação positiva;

- característica clínica da tontura (tontura rotatória, sensação de “cabeça oca”, desequilíbrio, flutuação escurecimento visual, sensação de queda e lateropulsão);

- característica clínica do zumbido. 


\subsection{Análise estatística}

Para avaliação estatística foram empregados o teste do Qui-quadrado e o teste $t$ de Student para duas amostras independentes.

O nível de significância adotado foi de 5\%, conforme proposto para modelos biológicos. 
5 RESULTADOS 
A amostra total foi constituída por 75 pacientes com diagnóstico de distúrbios do equilíbrio corporal de origem periférica. Com relação ao gênero, 76\% da amostra era composta por indivíduos do sexo feminino e $24 \%$ do sexo masculino. A idade variou de 18 a 74 anos, com média de 50,4 anos (desvio-padrão: 13,375).

\subsection{Prick test}

Foram encontrados 25 indivíduos que apresentaram prick test positivo (33,33\% do total da amostra). No grupo dos pacientes com prick test positivo a média de idade foi de 45,68 anos; e, no grupo de pacientes com prick test negativo, a média foi de 52,78 anos. Quando foi avaliada a idade dos pacientes, os indivíduos que apresentaram positividade no prick test eram mais jovens do que os com resposta negativa ao teste $(p=0,029)$. Não houve diferença estatisticamente significativa em relação ao gênero $(p=0,390)$.

Dos 75 indivíduos avaliados, 25 (33,33\%) ( IC $_{95 \%}=22,9 \%$ a 45,2\%) apresentaram prick test positivo a pelo menos um dos 13 alérgenos inalantes testados. Em relação aos antígenos alimentares testados, apenas seis pacientes (8\%) $\left(\mathrm{IC}_{95 \%}=3,0 \%\right.$ a 16,6\%) apresentaram reação positiva para pelo menos um alérgeno. Do total destes pacientes, quatro apresentaram prick test positivo na ausência de sintomas alérgicos (Anexo C). 
Todos os pacientes que apresentaram positividade a alérgenos alimentares, também reagiram a pelo menos um alérgeno inalante. Os antígenos inalantes que provocaram a maior porcentagem de resposta positiva foram a poeira domiciliar (88\%) e o ácaro (80\%), seguidos por epitélio de gato (44\%), epitélio de cão (40\%), barata (36\%), pena (12\%), algodão (12\%) e capim (12\%). Em menor porcentagem, foi documentada a positividade ao piretro, fungos do ar e macela em $8 \%$ dos indivíduos e os demais antígenos (gramínea e flor), provocaram reação em 4\% dos indivíduos. Dentre os alérgenos alimentares, o que apresentou positividade mais alta na população analisada foi o milho (20\%), seguido pelo glúten (8\%), soja (8\%), amendoim (8\%) e trigo (4\%).

A prevalência de hipersensibilidade do tipo I a pelo menos um dos antígenos utilizados foi de 33,33\%. Todos os pacientes contidos nessa porcentagem reagiram a pelo menos um inalante e $8 \%$ deles também responderam a pelo menos um antígeno alimentar (Anexo D).

\subsubsection{Caracterização dos sintomas}

Dos 75 pacientes analisados, a maior parte apresentou dois ou três tipos clínicos diferentes de tontura (Tabela 2). 
Tabela 2. Quantificação dos tipos clínicos de tontura apresentada por 75 pacientes da amostra.

\begin{tabular}{l|c|c|c|c|c}
\hline \hline \multirow{2}{*}{ Prick test } & \multicolumn{4}{|c|}{ Tipos clínicos de tontura } & \multirow{2}{*}{$\begin{array}{c}\text { Total } \\
\text { de } \\
\end{array}$} \\
\cline { 2 - 5 } & $\mathbf{1}$ & $\mathbf{2}$ & $\mathbf{3}$ & $\mathbf{4}$ & pacientes \\
\hline positivo & $5(20 \%)$ & $14(56 \%)$ & $6(24 \%)$ & 0 & 25 \\
negativo & $10(20 \%)$ & $20(40 \%)$ & $19(38 \%)$ & $1(2 \%)$ & 50 \\
\hline Total & $15(20 \%)$ & $34(45,33 \%)$ & $25(33,33 \%)$ & $1(1,33 \%)$ & 75 \\
\hline \hline
\end{tabular}

$\overline{\mathrm{N}}$ = quantidade de pacientes e respectiva porcentagem no grupo analisado

Os 25 indivíduos com prick test positivo foram caracterizados clinicamente quanto aos tipos de tontura que apresentavam. Quando comparados os dois grupos entre si, não houve diferença estatisticamente significante em relação à distribuição dos diferentes quadros de tontura apresentados entre os grupos (Tabela 3). 
Tabela 3. Distribuição dos diversos tipos de tontura em pacientes com prick test positivo e com prick test negativo.

\begin{tabular}{lc|c|c}
\hline \hline Tipo de tontura & $\begin{array}{c}\text { prick test positivo } \\
\mathbf{N}=\mathbf{2 5}\end{array}$ & $\begin{array}{c}\text { prick test negativo } \\
\mathbf{N}=\mathbf{5 0}\end{array}$ & $\begin{array}{c}\mathbf{p} \\
\mathbf{N}=\mathbf{7 5}\end{array}$ \\
\hline Rotatória & $22(88 \%)$ & $38(76 \%)$ & 0,358 \\
Sensação de cabeça oca & $10(40 \%)$ & $15(30 \%)$ & 0,544 \\
Desequilíbrio & $5(20 \%)$ & $18(36 \%)$ & 0,250 \\
Sensação de flutuação & $7(28 \%)$ & $11(22 \%)$ & 0,774 \\
Escurecimento visual & $3(12 \%)$ & $10(20 \%)$ & 0,590 \\
Sensação de queda & $1(4 \%)$ & $9(18 \%)$ & 0,186 \\
Lateropulsão & $1(4 \%)$ & $7(14 \%)$ & 0,355 \\
\hline \hline
\end{tabular}

$\overline{\mathrm{N} \text { = quantidade de pacientes e porcentagem; } \mathrm{p} \text { = significância para o teste do Qui-quadrado com }}$ correção de Yates

O zumbido foi relatado por 21 (84\%) dos 25 pacientes com prick test positivo. Em relação aos 50 pacientes com prick test negativo, o zumbido foi referido por 44 (88\%) pacientes. Não houve diferença estatisticamente significante entre os dois grupos $(\mathrm{p}=0,326)$ em relação à presença de zumbido. Os pacientes com zumbido perceberam-no em diversas freqüências (Tabela 4). 
Tabela 4. Distribuição dos pacientes com zumbido segundo sua frequência, nos grupos de pacientes com prick test positivo ou negativo

\begin{tabular}{l|c|c}
\hline \multirow{2}{*}{ Frequência de zumbido } & \multicolumn{2}{c}{ prick test } \\
\cline { 2 - 3 } & $7(33,33 \%)$ & $23(52,27 \%)$ \\
\hline alta & $7(33,33 \%)$ & $9(20,45 \%)$ \\
baixa & $7(33,33 \%)$ & $12(27,27 \%)$ \\
mista (alta e baixa) & \multicolumn{2}{c}{4} \\
\hline Total de pacientes com zumbido & 21 & 44 \\
\hline \hline
\end{tabular}

Em oito (38,1\%) dos 21 pacientes com prick test positivo e zumbido, houve relato de intensificação do sintoma durante a tontura. A mesma queixa foi relatada por 15 (34,1\%) dos 44 pacientes com prick test negativo e zumbido. Não houve diferença estatisticamente significativa entre os dois grupos $(\mathrm{p}=0,787)$. 
6 DISCUSSÃO 
A tontura é uma queixa muito comum na prática clínica assim como reações de hipersensibilidade a inalantes e a alimentos. Documentar uma provável relação causal entre reações de hipersensibilidade a alérgenos e tontura é uma atitude que abre um leque de oportunidades para o tratamento das vestibulopatias. A partir da prevalência de reações de hipersensibilidade a inalantes e a alimentos na população de pacientes com tontura, é possível buscar implicações fisiopatológicas das reações de hipersensibilidade no desenvolvimento das vestibulopatias periféricas.

No presente estudo, optamos por trabalhar com uma amostra de conveniência. Estudos de prevalência exigem um tamanho de amostra bem maior do que a obtida neste estudo, o que gerou um intervalo de confiança grande, tanto para a prevalência de hipersensibilidade alimentar quanto para a de hipersensibilidade a inalantes.

Em nossa amostra, o valor encontrado de 8\% de prevalência de hipersensibilidade a alimentos é maior do que o de $1 \%$ a $3 \%$ descrito para a população em geral (Björkstén, 2001), embora ambos os valores estejam dentro do $\mathrm{IC}_{95 \%}$ (3,0 a 16,6\%) que é amplo, devido ao tamanho da nossa amostra. Esse dado nos sugere que é possível que exista relação entre reações de hipersensibilidade a alimentos e vestibulopatia, conforme relatos de literatura (Duke, 1923; Wilson, 1972; Shaver, 1975; Powers, 1975; Endicott, Stucker, 1977; Derebery, Valenzuela, 1992; Derebery, 1996, 1997, 2000a, 2000b; Derebery, Berliner, 2000). É importante ressaltar que reações alimentares podem ocorrer pelo tipo de hipersensibilidade imediata (reação tipo I de Gell e Coombs, 1963), como também por deposição de 
imunocomplexos circulantes (tipo III de Gell e Coombs, 1963) e reação de hipersensibilidade retardada (tipo IV de Gell e Coombs, 1963). As reações tipo III e tipo IV não podem ser avaliadas por meio do prick test (Tipton, 1983), fato que poderia subestimar a prevalência de hipersensibilidade alimentar encontrada no presente estudo.

Vários autores atribuem à deposição de ICC (reação tipo III) no saco endolinfático às reações locais na determinação da hidropisia (Brookes, 1986; Hsu et al., 1990; Derebery et al., 1991). No presente estudo as reações por ICC não foram consideradas, uma vez que só foi determinada a prevalência de hipersensibilidade alimentar por meio do prick test que permite detectar apenas reações de hipersensibilidade imediata (tipo I).

Atenção especial deve-se dar ao fato de que utilizamos um número restrito (apenas cinco) de alérgenos alimentares para o prick test. Dados de história alimentar de pacientes da amostra revelaram possíveis reações de hipersensibilidade e/ou intolerância alimentar a outros alimentos, cujos extratos antigênicos não foram disponibilizados para a realização do teste. Alguns pacientes referiram sintomas de hipersensibilidade e/ou intolerância (urticária, disfonia, cólicas ou diarréia) a alguns alimentos (leite, maionese, carne bovina, carne suína, salsicha, sardinha, camarão, aveia, café, mandioca, agrião, abacaxi e manga) que não foram testados. Essas observações nos levam a acreditar que a prevalência de alergia alimentar na população de portadores de vestibulopatia possa mais uma vez ter sido subestimada uma vez que os alérgenos referidos não foram testados neste estudo para o cálculo da prevalência. 
Até o presente momento, discute-se muito a questão de métodos precisos para determinar reações alimentares. Alguns autores defendem a realização de um diário da ingesta alimentar do indivíduo, durante duas semanas, orientando o paciente a relacionar a freqüência dos alimentos ingeridos com o surgimento de determinado sintoma (dieta de inclusão / exclusão) (Clarke et al., 1996). São descritos ainda alguns testes in vitro para determinação de alergia alimentar, como a dosagem sérica de Imunoglobulina E específica a determinados antígenos, testes de liberação de histamina e o teste citotóxico de leucócitos. Entretanto, é importante ter em mente que níveis altos de imunoglobulinas ou de leucócitos reativos não garantem necessariamente que a doença está clinicamente presente. Resultados positivos devem ser relacionados à história clínica de reação alimentar do indivíduo. Para testes in vivo, é citado o teste de provocação oral que é considerado padrão-ouro para alergia alimentar (Sicherer, 1999). Porém, este teste não é seguro por causa do risco de desenvolvimento de reação anafilática (Gordon, 2003), motivo pelo qual não foi aplicado neste estudo.

Um resultado negativo ao prick test não pode excluir hipersensibilidade alimentar, pois a via de estimulação antigênica percutânea é diferente da estimulação oral. Sendo assim, o fato de termos considerado positivos apenas os pacientes com positividade aos alérgenos testados ao prick test pode ter gerado alguns resultados falso-negativos, o que poderia ter subestimado o valor de prevalência encontrado.

Acreditamos, portanto, que a porcentagem de pacientes com hipersensibilidade alimentar entre os indivíduos da amostra seja maior, mesmo porque alguns pacientes referiram reação alimentar a alguns outros alimentos que não foram testados ao prick test. 
Em relação aos achados de hipersensibilidade a inalantes em nossa amostra, é possível que exista relação entre reações de hipersensibilidade a inalantes e vestibulopatias periféricas, uma vez que, em relação a outros estudos de prevalência que temos disponíveis (Sole et al., 2006; AILA, 2009), a prevalência encontrada de 33,33\% pode ser maior do que a da população em geral.

Segundo estudo do ISAAC - fase três (Solé et al., 2006), a prevalência de doenças atópicas encontrada no Brasil foi em torno de 30\%. Porém, este estudo foi realizado somente em crianças, por meio de questionário para investigar a presença de sintomas de rinite não infecciosa, sem entrar no mérito se foram causadas por contato com antígenos (atopia) ou apenas irritantes inespecíficos. Ou seja, entraram na prevalência todas as rinites inflamatórias não infecciosas. Dessa forma, o valor encontrado pode ter sido superestimado.

Recentemente, foi concluído outro estudo de prevalência de alergia na América Latina (AILA, 2009) que, no Brasil, chegou a uma prevalência em torno de 9\%. O estudo incluiu pacientes com diagnósticos prévios de rinite alérgica (diagnóstico este realizado por profissionais médicos, de serviços variados, sem critério específico). Neste caso, o valor encontrado pode ter sido subestimado, uma vez que não foi seguido um protocolo específico para o diagnóstico inicial de rinite alérgica.

Dessa forma, considerando-se os dois estudos disponíveis, supomos um valor teórico médio aproximado de 15\% (Mello Junior, 2009) para a prevalência de rinite alérgica na população em geral. Portanto, os dados encontrados de prevalência de hipersensibilidade a inalantes na população de indivíduos com vestibulopatia periférica $(33,3 \%)$ foram maiores do que os $15 \%$ estimados de atopia para a 
população em geral. Por outro lado, a prevalência de 33,33\% encontrada no presente estudo apoiou-se na positividade do prick test. Sabe-se que o valor preditivo negativo (vpn) do prick test para rinite alérgica é de 93,3\% e o valor preditivo positivo (vpp) de 48,7\% (Tschopp et al., 1998). Assim, aproximadamente 50\% dos testes alérgicos positivos encontrados podem não significar doença (rinite alérgica) de fato. Sob este ângulo, a prevalência de rinite alérgica entre os pacientes com vestibulopatia periférica encontrada de 33,33\%, cai para algo em torno de 15\% (considerando-se o vpp de 48,7\% do teste alérgico). Assim, os pacientes que apresentaram prick test positivo para inalantes podem ser sensíveis a eles sem, no entanto, apresentar rinite alérgica. Cabe então indagar se é uma coincidência ou se algumas formas de vestibulopatia periférica corresponderiam a uma outra manifestação das atopias, ao lado da rinite, da asma e da dermatite atópica. Para confirmar essa hipótese, seria interessante aplicar nesses pacientes os testes de provocação com os antígenos.

Apesar dos argumentos aqui usados, deve-se lembrar que a amostra do presente estudo é pequena para que sejam obtidos dados mais fidedignos de prevalência. Sob este aspecto, a ampliação da amostra poderia gerar resultado diferente do que se encontra na literatura. De qualquer forma, os resultados de prevalência de hipersensibilidade encontrados na amostra analisada são bem menores aos alcançados por Derebery e Berliner (2000), que relatam 41,6\% de alergia a inalantes e $26,6 \%$ de alergia a alimentos em pacientes com DM.

Entre as queixas de tontura, a vertigem foi a mais comum entre todos os pacientes da amostra, sendo o tipo de tontura mais comum no grupo de pacientes com teste alérgico positivo, poderia sugestionar que existe relação causal entre hipersensibilidade a alérgenos e hidropisia, como a maioria dos autores coloca 
(Williams, 1952; Seymour, 1954; Shaver, 1975; Endicott, 1977; Brookes, 1986; Latkowski, 1987; Miyamura et al., 1987; Hsu et al., 1990; Derebery, Valenzuela, 1992; Uno et al., 1992; Viscomi, Borjab, 1992; Derebery, 1997; Derebery, Berliner, 1998; Gibbs et al, 1999; Derebery, 2000a, 2000b; Kelles et al., 2004; Derebery, Berliner, 2007). Entretanto, a vertigem também foi a apresentação clínica de tontura mais comum entre os pacientes com teste alérgico negativo.

A concomitância de zumbido e tontura em proporção semelhante nos dois grupos, positivo e negativo, é um fato discordante da associação entre alergia e vestibulopatia periférica, especialmente falando-se de DM. Sendo assim, poderíamos propor um novo modelo de pesquisa em que pacientes com tontura poderiam ser submetidos a testes de provocação antigênica e eletrococleografia, conforme documentação já existente na literatura (Viscomi, Bojrab, 1992; Gibbs et al., 1999; Noell et al., 2001). Tal estudo poderia investigar melhor a relação entre hidropsia e hipersensibilidade a alérgenos.

Outro dado a ser discutido ainda é o fato dos pacientes mais jovens apresentarem maior positividade ao prick test. Entretanto, o achado é esperado, pois, com o envelhecimento, o prick test tende a não apresentar respostas exuberantes mesmo nos pacientes com sabida hipersensibilidade.

É interessante notar que alguns pacientes que apresentaram teste alérgico positivo não referiam sensibilidade na anamnese. Esse fato sugere que possamos estar diante de indivíduos "sensibilizados". Nesse caso, essa sensibilização manifestar-se-ia por meio de uma síndrome atópica ainda não estabelecida: a vestibulopatia periférica.

Por fim, os estudos de prevalência são fundamentais na pesquisa e 
esclarecimento das doenças, e ampliam e aprofundam os conhecimentos existentes. Só é possível estabelecer critérios de avaliação, investigação e, por fim, o tratamento das doenças, se conhecermos de que maneira se apresentam e como se manifestam nas populações. 
7 CONCLUSÕES 
A prevalência encontrada de hipersensibilidade tipo I a inalantes e alimentos foi maior do que os dados disponíveis de prevalência na população em geral.

A vertigem foi o tipo de manifestação clínica de tontura mais comum entre todos os pacientes da amostra, não havendo diferença estatisticamente significante entre os pacientes com prick test positivo ou negativo. 
ANEXOS 


\section{ANEXO A}

Questionário para caracterização clínica de tontura, audição e/ou zumbido

\section{IDENTIFICAÇÃO}

Nome: RG-HC

Idade:

Sexo: Raça:.....

Profissão:

Endereço:

Telefone: (.........)......

Data:

Examinador:

2. TONTURA: ( ) sim ( ) não

Início:

Tipo de tontura: ( ) desequilíbrio ( ) rotatória ( ) “cabeça oca” ( ) flutuação ( ) escurecimento de visão （ ) perda de consciência
( ) lateropulsão: D E
( ) queda
( ) gota

( ) outras:

Cefaléia: ( ) sim ( ) não

Náusea: ( ) sim （） não

Vômito: ( ) sim （ ) não

Tendência a queda: ( ) sim [direita / esquerda / frente / posterior] ( ) não

Desvio da marcha: ( ) sim [ direita / esquerda ] não

Caracterização da tontura: ( ) em crises ( ) persistente

Duração da tontura: ( ) segundos ( ) minutos ( ) horas ( ) dias

Intensidade: ( ) leve （ ) moderada （ ) intensa （ ) variável 
Ocorrência: ( ) esporádica （ ） diária （ ） semanal [..............vezes]

( ) mensal [............vezes]

Relação com menstruação: ( ) sim [ antes / durante / após ] não

Fatores desencadeantes ou de piora: ( ) sim （ ) não （ ) não sabe

( ) movimentos da cabeça. Quais?.

( ) mudanças de posição do corpo. Quais?.

( ) veículos ( ) paroxismo [ direita / esquerda ]

( ) dieta. Qual? .......................................................................... ( ) jejum

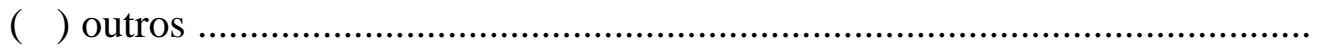

3. ZUMBIDO: ( ) ausente

( ) presente. Coincide com a tontura? ( ) sim （） não

Tempo de início:

Localização: OD ( ) $\quad$ OE ( ) cabeça $(\quad)$

Tipo: （ ) apito ( ) chiado ( ) pulsátil

( ) outros:.....

Evolução: ( ) constante ( ) intermitente

Interferência: ( ) sono （ ) concentração （ ) emocional （ ) social

4. PERDA AUDITIVA: ( ) ausente

( ) presente. Coincide com a tontura? ( ) sim ( ) não

Tempo de início:

Localização: OD ( ) OE ( ) cabeça $(\quad)$

Tipo: ( ) súbita ( ) progressiva （ ) estável （ ) flutuante

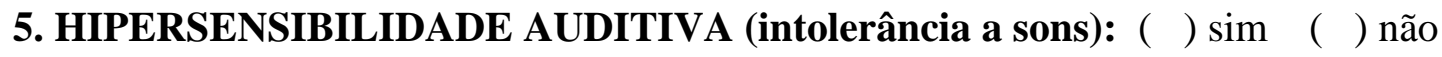


6. PLENITUDE AURICULAR: ( ) sim [ OD / OE ] （ ) não

7. GRAVIDADE:

$\begin{array}{llllllllllll}\text { Tontura: } & 0 & 1 & 2 & 3 & 4 & 5 & 6 & 7 & 8 & 9 & 10 \\ \text { Zumbido: } & 0 & 1 & 2 & 3 & 4 & 5 & 6 & 7 & 8 & 9 & 10 \\ \text { Hipoacusia: } & 0 & 1 & 2 & 3 & 4 & 5 & 6 & 7 & 8 & 9 & 10 \\ \text { Hipersensibilidade auditiva } & 0 & 1 & 2 & 3 & 4 & 5 & 6 & 7 & 8 & 9 & 10\end{array}$

\section{ANTECEDENTES PESSOAIS:}

Patologias prévias:

Medicações em uso: ( ) não

Quais?

$$
\text { ( ) } \operatorname{sim}
$$




\section{ANEXO B}

\section{Questionário de sintomatologia alérgica a inalantes e alimentos}

\section{IDENTIFICAÇÃO:}

Nome:

Idade:

RG-HC:

2. ALERGIA: Tem algum tipo de alergia? ( ) sim( ) não

Quando era criança seu nariz costumava ficar entupido, escorrendo ou coçando quando em contato com?
( ) não
( ) não lembro
( ) poeira
( ) bolor (umidade)
( ) animais (gato ou cachorro)
( ) flores e plantas
( ) perfumes, inseticidas ou cheiros fortes
( ) alimentos. Quais?
( ) remédios. Quais?

Seu nariz costuma ficar entupido, escorrendo ou coçando quando em contato com? ( ) não
( ) poeira
( ) bolor (umidade)
( ) animais (gato ou cachorro)

( ) flores e plantas

( ) perfumes, inseticidas ou cheiros fortes

( ) alimentos. Quais?

( ) remédios. Quais?

Quando era criança tinha tosse, falta de ar ou chiado no peito quando em contato com?
( ) não
( ) não lembro
( ) poeira
( ) bolor ( umidade)
( ) animais ( gato ou cachorro) 

( ) flores e plantas
( ) perfumes, inseticidas ou cheiros fortes
( ) alimentos. Quais?
( ) remédios. Quais?

Tem tosse, falta de ar ou chiado no peito quando em contato com?

( ) não

( ) poeira ( ) bolor (umidade) ( ) animais (gato ou cachorro)

( ) flores e plantas ( ) perfumes, inseticida ou cheiros fortes

( ) alimentos. Quais?

( ) remédios. Quais?

Tem cólicas, vômitos ou diarréia quando come algum tipo de alimento?

( ) não

( ) sim. Quais alimentos?

Tem alergia na pele?

( ) não

( ) sim. Qual tipo?

Alguém de sua família (pais ou irmãos) tem?
( ) asma
( ) rinite
( ) alergia na pele
( ) não
( ) não sei dizer

3. MEDICAÇÕES EM USO: ( ) não

( ) $\operatorname{sim}$ Quais?. 
ANEXO C

Relação dos sintomas referidos aos alérgenos e da resposta específica ao prick test entre os pacientes da amostra que apresentaram prick test positivo

\begin{tabular}{|c|c|c|c|c|c|c|c|}
\hline \multirow{3}{*}{ Nome } & \multirow{3}{*}{$\mathbf{S}$} & \multirow{3}{*}{$\mathbf{I}$} & \multicolumn{4}{|c|}{ Sintomas de atopia } & \multirow{3}{*}{ prick test } \\
\hline & & & \multicolumn{2}{|c|}{ Infância } & \multicolumn{2}{|c|}{ Idade adulta } & \\
\hline & & & nasais & pulmonares & nasais & pulmonares & \\
\hline APRM & F & 19 & & & $1,3,6,7$ & & $\begin{array}{l}1,2,6,7,12,13 \\
15,18\end{array}$ \\
\hline AFBS & $\mathrm{F}$ & 39 & & & $1,6,7$ & & $1,2,10,12$ \\
\hline BBS & $\mathrm{F}$ & 34 & & & 1,3 & & $1,2,6$ \\
\hline CCM & $\mathrm{F}$ & 50 & & & $1,3,6,7$ & & $1,2,6$ \\
\hline $\mathrm{CBO}$ & $\mathrm{F}$ & 54 & & & $\begin{array}{l}1,3,4,5 \\
6,7,10\end{array}$ & & $1,2,6,7,8,9,10$ \\
\hline DFP & $\mathrm{F}$ & 57 & & & 1 & & $2,10,12$ \\
\hline DGM & $\mathrm{F}$ & 58 & & & $\begin{array}{l}1,3,4,5 \\
10\end{array}$ & 3 & $1,2,6,7,8,15$ \\
\hline DKD & $\mathrm{F}$ & 19 & & & 1 & & $1,2,6$ \\
\hline ICS & $\mathrm{F}$ & 33 & $1,3,6,7$ & 1,3 & 1,3 & 1,3 & $1,2,6,7$ \\
\hline IRS & $\mathrm{F}$ & 43 & & & 1 & & $1,2,6,7,11,12$ \\
\hline MGV & $\mathrm{F}$ & 66 & & & $1,3,5,6$ & & 1,3 \\
\hline MAC & $\mathrm{F}$ & 25 & & 1,3 & 13 & & 1,2 \\
\hline MIO & $\mathrm{F}$ & 51 & & & 1 & 1 & 1 \\
\hline MNPM & $\mathrm{F}$ & 40 & 1 & & 1 & & $1,2,7$ \\
\hline MSPS & $\mathrm{F}$ & 44 & & & 1,3 & & $1,2,12$ \\
\hline MFSL & $\mathrm{F}$ & 38 & & & 1,3 & 1 & 1,215 \\
\hline MCL & M & 54 & & $1,3,6,7$ & $1,3,6,7$ & $1,3,6,7$ & $\begin{array}{l}1,2,6,7,8,9,11 \\
12,14,17\end{array}$ \\
\hline PJR & M & 33 & & & 1 & & $1,2,6,7,12,15$ \\
\hline $\mathrm{RM}$ & $\mathrm{F}$ & 47 & $1,3,6,7$ & $1,3,6,7$ & $1,3,6,7$ & $1,6,7$ & 1 \\
\hline VTH & $\mathrm{F}$ & 54 & & & $\begin{array}{l}1,3,4,5 \\
10\end{array}$ & & $1,2,7$ \\
\hline WSS & $\mathrm{F}$ & 49 & & & 1 & 1 & $\begin{array}{l}1,2,3,4,5,6,7,9, \\
11,12,14,15,16, \\
17,18\end{array}$ \\
\hline ASSA & $\mathrm{F}$ & 56 & & & & & 1,2 \\
\hline $\mathrm{JF}$ & M & 58 & & & & & 13 \\
\hline JMI & M & 60 & & & & & 1,2 \\
\hline MAS & $\mathrm{F}$ & 61 & & & & & 12 \\
\hline
\end{tabular}

S = sexo; $\mathrm{F}$ = feminino; $\mathrm{M}$ = masculino; $\mathrm{I}$ = idade (anos);

Alérgenos:

1 - pó; 2 - ácaro; 3 - fungo; 4 - gramínea; 5 - flor; 6 - gato; 7 - cão; 8 - pena; 9 - algodão; 10 -capim; 11 - macela; 12 - barata; 13 - piretro; 14 - glúten; 15 - milho; 16 - trigo; 17 - soja; 18 - amendoim 
ANEXO D

Relação dos alérgenos em cada paciente com resposta positiva ao prick test

\begin{tabular}{|c|c|c|c|c|c|c|c|c|c|c|c|c|c|c|c|c|c|c|c|c|}
\hline \multirow{2}{*}{ Nome } & \multirow{2}{*}{$S$} & \multirow{2}{*}{ I } & \multicolumn{18}{|c|}{ Alérgenos } \\
\hline & & & a & b & c & d & e & $\mathbf{f}$ & g & $\mathbf{h}$ & $\mathbf{i}$ & $\mathbf{j}$ & $\mathbf{k}$ & I & $\mathbf{m}$ & $\mathrm{n}$ & o & $\mathbf{p}$ & $\mathbf{q}$ & $r$ \\
\hline APRM & $F$ & 19 & 1 & 1 & 1 & 1 & 1 & 0 & 0 & 0 & 1 & 0 & 0 & 1 & 0 & 1 & 0 & 0 & 0 & 0 \\
\hline AFBS & $\mathrm{F}$ & 39 & 1 & 1 & 0 & 0 & 1 & 0 & 0 & 0 & 0 & 0 & 1 & 0 & 0 & 0 & 0 & 0 & 0 & 0 \\
\hline BBS & F & 34 & 1 & 1 & 1 & 0 & 0 & 0 & 0 & 0 & 0 & 0 & 0 & 0 & 0 & 0 & 0 & 0 & 0 & 0 \\
\hline CCM & F & 50 & 1 & 1 & 1 & 0 & 0 & 0 & 0 & 0 & 0 & 0 & 0 & 0 & 0 & 0 & 0 & 0 & 0 & 0 \\
\hline CBO & F & 54 & 1 & 2 & 1 & 1 & 0 & 1 & 0 & 1 & 0 & 0 & 1 & 0 & 0 & 0 & 0 & 0 & 0 & 0 \\
\hline DFP & F & 57 & 0 & 1 & 0 & 0 & 1 & 0 & 0 & 0 & 0 & 0 & 1 & 0 & 0 & 0 & 0 & 0 & 0 & 0 \\
\hline DGM & F & 58 & 1 & 1 & 1 & 1 & 0 & 1 & 0 & 0 & 0 & 0 & 0 & 1 & 0 & 0 & 0 & 0 & 0 & 0 \\
\hline DKD & F & 19 & 1 & 1 & 1 & 0 & 0 & 0 & 0 & 0 & 0 & 0 & 0 & 0 & 0 & 0 & 0 & 0 & 0 & 0 \\
\hline ICS & $\mathrm{F}$ & 33 & 1 & 1 & 1 & 1 & 0 & 0 & 0 & 0 & 0 & 0 & 0 & 0 & 0 & 0 & 0 & 0 & 0 & 0 \\
\hline IRS & F & 43 & 1 & 1 & 1 & 1 & 1 & 0 & 0 & 0 & 0 & 0 & 0 & 0 & 0 & 0 & 0 & 0 & 0 & 0 \\
\hline MGV & $\mathrm{F}$ & 66 & 1 & 0 & 0 & 0 & 0 & 0 & 0 & 0 & 0 & 1 & 0 & 0 & 0 & 0 & 0 & 0 & 0 & 0 \\
\hline MIO & $\mathrm{F}$ & 51 & 1 & 0 & 0 & 0 & 0 & 0 & 0 & 0 & 0 & 0 & 0 & 0 & 0 & 0 & 0 & 0 & 0 & 0 \\
\hline MAC & $\mathrm{F}$ & 25 & 1 & 1 & 0 & 0 & 0 & 0 & 0 & 0 & 0 & 0 & 0 & 0 & 0 & 0 & 0 & 0 & 0 & 0 \\
\hline MNPN & $\mathrm{F}$ & 40 & 1 & 1 & 0 & 1 & 0 & 0 & 0 & 0 & 0 & 0 & 0 & 0 & 0 & 0 & 0 & 0 & 0 & 0 \\
\hline MSPS & F & 44 & 1 & 1 & 0 & 0 & 1 & 0 & 0 & 0 & 0 & 0 & 0 & 0 & 0 & 0 & 0 & 0 & 0 & 0 \\
\hline MFSL & F & 38 & 1 & 1 & 0 & 0 & 0 & 0 & 0 & 0 & 0 & 0 & 0 & 1 & 0 & 0 & 0 & 0 & 0 & 0 \\
\hline MCL & M & 54 & 1 & 1 & 1 & 1 & 1 & 1 & 1 & 1 & 0 & 0 & 0 & 0 & 1 & 0 & 1 & 0 & 0 & 0 \\
\hline PJR & M & 33 & 1 & 1 & 1 & 1 & 1 & 0 & 0 & 0 & 0 & 0 & 0 & 1 & 0 & 0 & 0 & 0 & 0 & 0 \\
\hline RM & F & 47 & 1 & 0 & 0 & 0 & 0 & 0 & 0 & 0 & 0 & 0 & 0 & 0 & 0 & 0 & 0 & 0 & 0 & 0 \\
\hline VTH & F & 54 & 1 & 1 & 0 & 1 & 0 & 0 & 0 & 0 & 0 & 0 & 0 & 0 & 0 & 0 & 0 & 0 & 0 & 0 \\
\hline WSS & F & 49 & 1 & 1 & 1 & 1 & 1 & 0 & 1 & 1 & 0 & 1 & 0 & 1 & 1 & 1 & 1 & 1 & 1 & 1 \\
\hline MAS & $\mathrm{F}$ & 61 & 0 & 0 & 0 & 0 & 1 & 0 & 0 & 0 & 0 & 0 & 0 & 0 & 0 & 0 & 0 & 0 & 0 & 0 \\
\hline ASSA & $\mathrm{F}$ & 56 & 1 & 1 & 0 & 0 & 0 & 0 & 0 & 0 & 0 & 0 & 0 & 0 & 0 & 0 & 0 & 0 & 0 & 0 \\
\hline JF & M & 58 & 0 & 0 & 0 & 0 & 0 & 0 & 0 & 0 & 1 & 0 & 0 & 0 & 0 & 0 & 0 & 0 & 0 & 0 \\
\hline JMI & M & 60 & 1 & 1 & 0 & 0 & 0 & 0 & 0 & 0 & 0 & 0 & 0 & 0 & 0 & 0 & 0 & 0 & 0 & 0 \\
\hline
\end{tabular}

$\mathrm{S}=$ sexo; $\mathrm{F}$ = feminino; $\mathrm{M}$ = masculino; $\mathrm{I}$ = idade (anos);

Alérgenos: a - poeira; b - ácaro; c - gato; d - cão; e - barata; f - pena; g - macela; h - algodão; i - piretro; $\mathrm{j}$ - fungos; $\mathrm{k}$-capim; $\mathrm{l}$-milho; $\mathrm{m}$-glúten; $\mathrm{n}$-amendoim; o-soja; $\mathrm{p}$-flor; $\mathrm{q}$-gramínea; $\mathrm{r}$-trigo;

$0=$ resposta negativa; 1 = resposta positiva 
8 REFERÊNCIAS BIBLIOGRÁFICAS 


\section{REFERÊNCIAS BIBLIOGRÁFICAS ${ }^{1}$}

AILA (Allergies in Latino America). Pesquisa multinacional em pacientes com rinite alérgica na América Latina. Resultados apresentados no XIX Congresso Mundial de Otorrinolaringologia em São Paulo, Brasil, Junho, 2009.

ALLEMAN AM, DORNHOFFER JL, ARENBERG IK, ALKER PD. Demonstration of autoantibodies to the endolymphatic sac in Meniere's disease. Laryngoscope. 1997;107(2):211-5.

ALTERMATT HJ, GEBBERS JO, MÜLLER C, ARNOLD W, LAISSUE JA. Human endolymphatic sac: evidence for a role in inner ear immune defense. ORL J Otorhinolaryngol Relat Spec. 1990;52:43-8.

BERGSTRÖM T, EDSTROM S, TJELLSTRÖM A, VAHLNE A. Meniere's disease and antibody reactivity to herpes simplex virus type 1 polypeptides. Am J Otolaryngol. 1992;13:295-300.

BROOKES GB. Circulating immune complexes in Ménière's disease. Arch Otolaryngol Head Neck Surg. 1986;112:536-40.

BJÖRKSTÉN B. The epidemiology of food allergy. Curr Opin Allergy Clin Immunol. 2001;1(3):225-7.

${ }^{1}$ De acordo com:

Adaptado de International Committee of Medical Journals Editors (Vancouver).

Universidade de São Paulo. Faculdade de Medicina. Serviço de Biblioteca e Documentação. Guia de apresentação de dissertações, teses e monografias da FMUSP. Elaborado por Anneliese Carneiro da Cunha, Maria Julia A.L. Freddi, Maria F. Crestana, Marinalva de S. Aragão, Suely C. Cardoso, Valéria Vilhena. 2a ed. São Paulo: Serviço de Biblioteca e Documentação; 2005.

Abreviaturas dos títulos dos periódicos de acordo com List of Journals Indexed in Index Medicus. 
CLARKE L, McQUEEN J, SAMILD A, SWAIN AR. Dietitians Association of Australia - Review paper. The dietary management of food allergy and food allergy and food intolerance in children in children and adults. Aust J Nutr Dietetics. 1996;53(3):89-98.

DEREBERY M.J. Allergic and immunologic aspects of Meniere's disease. Otolaryngol head Neck Surg. 1996;114:360-5.

DEREBERY MJ. Allergic management of Meniere's disease: an outcome study. Otolaryngol Head Neck Surg. 2000a;122(2):174-82.

DEREBERY MJ. Allergic reactions in the middle and inner ear. Current Opinion in Otolaryngol Head and Neck Surg. 2000b;8(3):245-8.

DEREBERY MJ. Prevalence of heat shock protein in patients with meniere's disease and allergy. Otolaryngol Head Neck Surg. 2002;126:677-82.

DEREBERY MJ. The role of allergy in Meniere's disease. Otolaryngol Clin North America. 1997;30(6):1007-17.

DEREBERY MJ, BERLINER KI. Allergy for the Otologist. Otolaryngol Clin North Am. 1998;31(1):157-73.

DEREBERY MJ, BERLINER KI. Allergy and Ménière's disease. Curr Allergy Asthma Rep. 2007;7(6):451-6.

DEREBERY MJ, BERLINER KI. Prevalence of allergy in Meniere's disease. Otolaryngol Head Neck Surg. 2000;123:69-75.

DEREBERY MJ, RAO VS, SIGLOCK TJ, LINTHICUM FH, NELSON RA. Ménière's disease: an immune complex-mediated illness? Laryngoscope. 1991;101(3):225-9. 
DEREBERY MJ, VALENZUELA S. Meniere's syndrome and allergy. Otolaryngol Clin North Am. 1992;25(1):213-24.

DUKE WW. Ménière's syndrome caused by allergy. JAMA, 1923;81(26):2179-81

EATON DA, ROLAND PS, MABRY RL, SHOUP AG. Eletrocochleography and intranasal allergen challenge as investigational tools in patients with inhalant allergy and Meniére's disease. Laryngoscope. 2003;113(1):33-6.

ENDICOTT JN, STUCKER FJ. Allergy in Ménière's disease related fluctuating hearing loss preliminary fingings in a double-blind crossover clinical study. Laryngoscope 1977;87:1650-7.

GELL PGH, COOMBS RRA, eds. Clinical Aspects of Immunology. 1st ed. Oxford, England: Blackwell; 1963.

GIBBS SR, MABRY RL, ROLAND PS, SHOUP AG, MABRY CS. Eletrocochleographic changes after intranasal allergen challenge: a possible diagnostic tool in patients with Meniere's disease. Otolaryngol Head Neck Surg. 1999;121(3):283-4.

GOEBEL JA, SIREVAAG EJ, SIMONS JP, ROHRBAUGGH JW. High frequency sway characteristics in the elderly. In: Equilibrium in research, equilibriometry and modern treatment, Claussen CF, Editor, Elsevier Science B.V. Amsterdam, 283-289, 2000.

GORDON BR. Approaches to testing for food and chemical sensitivities. Otolaryngologic Clinics of North America. 2003;36:917-40.

HARRIS JP. Immunology of the inner ear: evidence of local antibody production. Ann Otol Rhinol Laryngol. 1984;93:157-62. 
HSU L, ZHU XN, ZHAO YS. Immunoglobulin $\mathrm{E}$ and circulating immune complexes in endolymphatic hydrops. Ann Otol Rhinol Laryngol 1990;99:53538.

HUGHES GB, BARNA BP, KINNEY SE, CALABRESE LH, HAMID MA, NALEPA NJ. Autoimmune endolymphatic hydrops: five-years review. Otolaryngol Head Neck Surg. 1988;98(3): 221-5.

ISAAC - The International Study of Asthma and Allergies in Childhood Steering Committee. Worldwide variation in prevalence of symptoms of asthma, allergic rhinoconjunjunctivitis, and atopic eczema. Lancet. 1998;351:1223-32.

KROENKE K, MANGELSSDORFF AD. Common symptoms in ambulatory care: incidence, evaluation, therapy, and outcome. Am J Med 1989; 86:262-6.

KELES E, GÖDEKMERDAN A, KALIDAĞ T, KAYGUSUZ I, YALÇIN S, CENGIZ ALPAY H, ARAL M. Meniere's disease and allergy: allergens and cytokines. J Laryngol Otol. 2004;118(9):688-93.

LATKOWSKI B. Auxiliary treatment of vertigo of allergic aetiology with histaglobin. Pan Med. 1987;29:157-160.

McCABE BF. Autoimmune sensorineural hearing loss. Ann Otol Rhinol Laryngol. 1979;88:585-89.

MELLO JR JF. Comunicação pessoal em 12/09/2009.

MÉNIÈRE P. Pathologic auriculaire: m'moire sur des lesions de lóreille interne donnat lieu a des syntomes de congestion cérebrale apoplectiforme. Gaz Med Paris 1861;16:597-601. 
MIYAMURA K, KANZAKI Y, NAGATA M, ISHIKAWA T. Provocation of nystagmus and deviation by type I allergy in the inner ear of the guinea pig. Ann Allergy. 1987;58(1):36-40.

NOELL CA, ROLAND PS, MABRY RL, ANGELA G. Inhalant allergy and meniere's disease: use of eletrocochleography and intranasal allergen challenge as investigational tools. Otolaryngol Head Neck Surg. 2001;125(4):346-350.

POWERS WH. Allergic factors in Ménière's disease. Trans Am Acad Ophthalmol Otolaryngol. 1973;77:22-9.

POWERS WH. The role of allergy in fluctuating hearing loss. Otolaryngol Clin North Am. 1975;8(2):493-500.

PULEC L, HOUSE WF. Ménière's disease study: three years progress report. Int J Equilib Res. 1973;3(1):156-65.

RASK-ANDERSEN H, STAHLE J. Immunodefense of the inner ear? Lymphocytemacrophage interaction in the endolymphatic sac. Acta Otolaryngol (Stockh). 1980;89:283-94.

RAUCH SD, SAN MARTIN JE, MOSCICKI RA, et al. Serum antibodies against heat shock protein 70 in Meniere's disease. Am J Otol. 1995;16:648-42.

SEYMOUR JC. Observations on circulation in the cochlea. J Laryngol. 1954;68: 689-711.

SHAVER JR EF. Allergic management of Meniere's disease. Arch Otolaryngol. 1975;101(2):96-9.

SICHERER SH. Food allergy: when and how to perform oral food challenges. Pediatr Allergy Immunol. 1999;10:226-34. 
SOLÉ D, WANDALSEN GF, CAMELO-NUNES IC, NASPITZ CK, ISAAC BRAZILIAN GROUP. Prevalence of symptoms of asthma, rhinitis and atopic eczema among Brazilian children and adolescents identified by the International Study of Asthma and Allergies (ISAAC) - phase 3. J Pediatr. 2006;82 (5):341-46.

SOLÉ D, WECKX LLM, FILHO NAR, JÚNIOR JFM, et al. II Consenso Brasileiro sobre Rinites 2006. Rev Bras Alerg Imunopatol. 2006a;29(1):29-58.

SOLÉ D, SILVA L, ROSARIO FILHO NA, SARNI ROS. Consenso Brasileiro Sobre Alergia Alimentar: 2007. Rev Bras Alerg Imunopatol. 2008;31(2):64-89.

TIPTON, WR. Evaluation of skin testing in the diagnosis of IgE-mediated disease. Pediatric Clin North Am. 1983;30:785-93.

TOMIYAMA S, HARRIS JP. The role of the endolymphatic sac in inner ear immunity. Acta Otolaryngol. 1987;103:182-8.

TSCHOPP JM, SISTEK D, SCHINDLER C, LEUENBERGER P, PERRUCHOUD AP, WÜTHRICH B, BRUTSCHE M, ZELLWEGER JP, KARRER W, BRÄNDLI O, SAPALDIA team. Current allergic asthma and rhinitis: diagnostic efficiency of three commonly used atopic markers (igE, skin prick tests, and Phadiatop). Results from 8329 randomized adults from the SAPALDIA study. Allergy. 1998;53:608-613.

UNO K, MIYAMURA K, KANZAKI Y, FUKUDA H, MASUYAMA K, ISHIKAWA T. Type I allergy in the inner ear of guinea pig. Ann Otol Rhinol Laryngol Suppl. 1992;157:78-81.

VISCOMI GJ, BOJRAB DI. Use of eletrocochleography to monitor antigenic challenge in meniere's disease. Otolaryngol Head and Neck Surg. 1992;107:73337. 
WILLIAMS HL. Meniere's disease. Springfield, III, Charles C Thomas Publishers, 1952.

WILSON WW. Antigenic excitation in Ménière's disease. Laryngoscope 1972;82:1726-35. 
APÊNDICE 


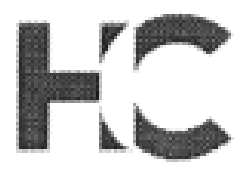

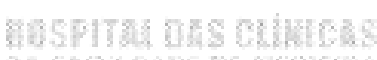

\section{DIRETORIA CLÍNICA}

\section{Comissão de Ética para Análise de Projetos de Pesquisa}

\section{APROVACEÃO}

O Presidente da Comissāo de Ética para Análise de Projetos de Pesquisa - CAPPesq da Diretoria Clínica do Hospital das Clínicas e da Faculdade de Medicina da Universidade de São Paulo, APROVOU, ad referendum, o Protocolo de Pesquisa $n^{\circ} 867 / 03$ intitulado "Prevalência de atopia em indivíduos com distúrbio do equilibrio corporal", apresentado pelo Departamento de OFTALMOLOGIA E OTORRINOLARINGOLOGIA, inclusive o Termo de Consentimento Livre e Esclarecido.

Pesquisador Responsável: Dra, Roseli Saraiva Moreira Bittar Pesquisadora Executante: Dra, Erika Cisi Domingues

CAPPesq, 16 de Dezembro de 2003.

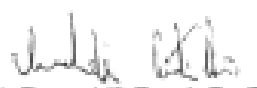

PROF. DR. EUCLIDES AYRES DE CASTILHO Presidente da Comissöo Ética para Análise de Projetos de Pesquisa

OBSERVAÇÃO: Cabe ao pesquisador elabarar e apresentar a CAPPesq. os nelatórios parciais e final sobre a pesquisa (Resalucgäo do Conselho Nocrional de Saúde n"196. de 10,10,1996, inciso IX,2, lefra "c? 


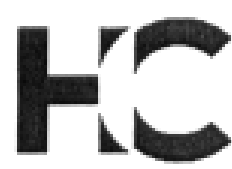

\section{DIRETORIA CLÍNICA}

\section{Comissão de Ética para Análise de Projetos de Pesquisa}

\section{APROVAÇÃO}

A Comissão de Ética para Análise de Projetos de Pesquisa - CAPPesq da Diretoria Clínica do Hospital das Clínicas e da Faculdade de Medicina da Universidade de São Paulo, em sessão de 27.05.04, APROVOU, alterações realizadas no Protocolo de Pesquisa $n^{\circ}$ 867/03 - intitulado "Prevalência de atopia em indivíduos com distúrbio do equilibrio corporal", bem como mudança de título para: "Prevalência de alergia em indivíduos com distúrbio do equilibrio corporal", e o Novo Termo de Consentimento Livre e Esclarecido.

DEPARTAMENTO DE OFTALMOLOGIA E OTORRINOLARINGOLOGIA

Pesquisador(a) Responsável: Dra. Roseli Saraiva Moreira Bittar

Pesquisador (a) Executante: Dra. Erika Cisi Domingues

CAPPesq, 27 de Maio de 2004.

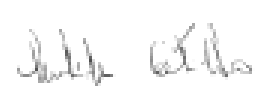

PROF. DR. EUCLIDES AYRES DE CASTILHO

Presidente da Comissão de Ética para Análise de Projetos de Pesquisa

OBSERVAÇÃO: Cabe ao pesquisador elaborar e apresentar a CAPPesq, os relatórios parciais e final sobre a pesquisa (Resoluçäo do Conseltho Nacional de Saúde $n^{\circ}$ 196, de 10.10.1996, inciso IX.2, letra "c? 